This PDF is a selection from a published volume from the National Bureau of Economic Research

Volume Title: Investment in Human Beings

Volume Author/Editor: Universities-National Bureau Committee for Economic Research

Volume Publisher: The Journal of Political Economy Vol. LXX, No.

5, Part 2 (University of Chicago Press)

Volume ISBN: 0-87014-306-9

Volume URL: http://www.nber.org/books/univ62-3

Conference Date:

Publication Date: October 1962

Chapter Title: On-the-Job Training: Costs, Returns, and Some Implications

Chapter Author(s): Jacob Mincer

Chapter URL: http://www.nber.org/chapters/c13572

Chapter pages in book: (p. 50 - 79) 


\title{
ON-THE-JOB TRAINING: COSTS, RETURNS, AND SOME IMPLICATIONS ${ }^{1}$
}

\author{
JACOB MINCER \\ Columbia University and National Bureau of Economic Research
}

\section{INTRODUCTION}

I $\mathrm{N}$ THE context of the economist's concern with education as a process of investment in manpower, it is important to be reminded that formal school instruction is neither an exclusive nor a sufficient method of training the labor force. Graduation from some level of schooling does not signify the completion of a training process. It is usually the end of a more general and preparatory stage, and the beginning of a more specialized and often prolonged process of acquisition of occupational skill, after entry into the labor force. This second stage, training on the job, ranges from formally organized activities such as apprenticeships and other training programs ${ }^{2}$ to the in-

\footnotetext{
1 This work was stimulated and made possible by Gary Becker's fundamental theoretical analysis of investment in human capital. H. G. Lewis contributed very thoughtful and useful comments on the first version of the paper. I am also indebted for helpful comments to T. W. Schultz, G. H. Moore, G. P. Shultz, Z. Griliches, and H. Gilman. Dave O'Neill provided highly competent research assistance. Financial support by the Carnegie Corporation of New York is gratefully acknowledged.
}

${ }^{2}$ A good sample of a growing literature on the subject includes P. H. Douglas, American Apprenticeship and Industrial Education (New York: Columbia University Press, 1921); United States Department of Labor, Bureau of Apprenticeship and Training, Apprenticeships Past and Present (Washington, 1955); Apprentice Training (Washington, 1956); and Employee Training in New Jersey Industry (Washington, 1960); National Manpower Council, A Policy for Skilled Manpower (New York: Columbia University Press, 1954) and Improving the Work Skills of the Nation (New York: Columbia University Press, 1955); H. F. Clark, and H. S. Sloan, Classrooms in the Factories (Rutherford, N.J.: Fairleigh Dickinson College, 1958); O. N. Serbein, $E d u$ cational Activilies of Business (Washington: American Council on Education, 1961). formal processes of learning from experience. Indeed, historically, skills have been acquired mainly by experience on the job. The vast schooling system and the delayed entry into the labor force are distinctly modern phenomena.

As history suggests, it is useful to view the two broad classes of training not only as a sequence of stages but also as alternatives or substitutes. In many cases, the same degree of occupational skill can be achieved by "shortening" formal schooling and "lengthening" on-the-job training or by the reverse. The degree of substitutability between the two will, of course, vary among jobs and over time with changes in technology.

When training is viewed as a process of capital formation in people, three major empirical questions may be raised for economic analysis. (1) How large is the allocation of resources to the training process? (2) What is the rate of return on this form of investment? (3) How useful is knowledge about such investments in explaining particular features of laborforce behavior?

Recently flourishing research in these areas provides some tentative answers. ${ }^{3}$ T. W. Schultz estimated the amount and growth of resources devoted by the economy to formal education. G. S. Becker

${ }^{3}$ G. S. Becker, "Investment in People" (unpublished manuscript, National Bureau of Economic Research, 1961), and his "Underinvestment in College Education?" American Economic Review, Papers and Proceedings, May, 1960; T. W. Schultz, "Capital Formation in Education," Journal of Political Economy, December, 1960, and his "Investment in Human Capital," American Economic Review, March, 1961. 
estimated the rate of return to training at higher levels of education. In his $\mathrm{Na}$ tional Bureau of Economic Research study, now in progress, Becker outlines the capital-theoretical approach to investment in people and shows it to be a tool of great analytical power and of extensive empirical relevance.

My first task in this paper is to estimate the amount of investment in onthe-job training. The estimates are indirect, and the concept of on-the-job training rather broad, but I am hopeful that results are at least suggestive of the orders of magnitude involved. The estimates and a discussion of their limitations are given in the first section of the paper. In the second section I attempt to estimate rates of return on some particular forms of on-the-job training, such as apprenticeships and medical specialization. The results are then compared with the rates of return on investment which includes both components: formal education and on-the-job training. In consequence, some tentative inferences are formulated about the separate components. In the final section of the paper I consider some preliminary empirical implications of my results. In particular, differentials in on-the-job training are related to income and employment differentials among population subgroups, classified by levels of education, occupation, sex, and race. The observed behavior patterns seem largely consistent with the investment hypothesis underlying this study, though it was not possible in this preliminary empirical exploration to control for all other important factors at play.

\section{ESTIMATES OF COSTS OF ON-THE-JOB TRAINING}

For the purpose of this paper, the term "training" denotes investment in ac- quisition of skill or in improvement of worker productivity. The concept, therefore, includes schooling and training obtained on the job. The latter, under this definition, is a much broader concept than what is conveyed by the common usage of the word "on-the-job training." It includes formal and informal training programs in a job situation, as well as what is called "learning from experience."

The method of estimating the volume of investment in on-the-job training, which is described in this section, treats "learning from experience" as an investment in the same sense as are the more obvious forms of on-the-job training, such as, say, apprenticeship programs. Put in simple terms, an individual takes a job with an initially lower pay than he could otherwise get because he knows that he will benefit from the experience gained in the job taken. ${ }^{4}$ In this sense, the opportunity to learn from experience involves an investment cost which is captured in the estimation method.

While data are much more scarce and the arithmetic is more arduous, calculation of on-the-job training costs is guided by the same theoretical principles ${ }^{5}$ as the calculation of schooling costs. Costs of schooling consist of direct outlays (private tuition and public support), and of indirect, "invisible" opportunity costs,

${ }^{4}$ This proposition is sometimes questioned on the basis of casual observation. Greater learning from experience is characteristic of workers with greater motivation and ability, and their earnings at the early stages of the career may in some cases be as high or higher than those of other workers. But such finding that people with greater ability have higher productivity than others at any given stage of experience does not negate the existence of investment in on-the-job training, though it may bias the estimation of its magnitude.

5 The conceptual and mathematical framework are developed and stated in Becker's "Investment in Human Capital: A Theoretical Analysis," in this Supplement. 
such as foregone earnings of students resulting from the necessary reduction of their labor-force activities while at school. Once the direct outlays are known, it is possible to infer the costs of an increment of schooling from comparative data on earnings of two sets of individuals: students, and people similar to them with respect to previous educational attainment, age, sex, ability, except that they are "economically active" in the labor force and do not engage in additional schooling. In empirical work these conditions are approximated as well as data permit.

According to the available calculations, ${ }^{6}$ foregone earnings constitute over half of total costs of schooling and about 75 per cent of the costs borne by students. Foregone earnings bulk even more in the costs borne by trainees on the job. Indeed, nowadays it is difficult to think of any important direct payments by trainees, though in the past it was not uncommon for apprentices to pay their masters for the training. This does not mean, however, that no direct outlays are incurred in the training of workers on the job. Firms do spend sizable sums to finance apprenticeships and other training programs: equipment must be purchased and instructors paid. These sums presumably appear in accounts of firms as costs of training workers, though such data are rarely available.

Should all or a part of firm outlays be added to the sum of foregone earnings of workers to arrive at a total figure of costs of on-the-job training, indirect and direct? The answer is no, if all of the firm outlays are currently charged to the worker in the form of a reduction in wages. In this case the worker buys training services from the firm. The cost of the purchase is simply part of his fore-

\footnotetext{
${ }^{6}$ See references in n. 3 .
}

gone earnings - the other part being the difference between the actual marginal product of the trainee and the larger amount he could produce if he did not engage in training. Adding firm outlays in this case would constitute double counting.

It is likely, however, that some fraction of firm outlays is not charged currently to the workers but recouped by the firm at a later date. ${ }^{7}$ The part of firm outlays which is not matched by current reductions in wages of trainees should be added to foregone earnings of workers. Unfortunately, it is impossible to estimate how large a fraction of firm outlays are costs borne by the firm. Worse yet, data on costs of training (whether borne by firms or workers) are not only scarce but, in principle, highly unreliable. Such items as loss of production by experienced workers who are helping the trainees or wear and tear of equipment do not show up in any entry as direct costs of training. Rather, they are likely to be hidden in the wage and depreciation costs. Even if all costs of training were borne by firms, so that they would also pay all the foregone earnings of workers, only a fraction of costs would be revealed by accounting data. I conclude that an attempt to gauge costs of on-the-job training in the economy by accounting data of firms, even if they were made available, would lead to severe underestimates.

On the other hand, working with earnings data of workers to estimate

\footnotetext{
${ }^{7}$ Under competitive conditions, all of the firm's costs will be charged to the worker if the training increases his future productivity in other firms just as much as in the firm in which he is training. Some fraction of costs will not be charged to the worker if the training contains elements of specificity, that is, if it increases the worker's future productivity in the firm more than in other firms. For a full exposition see Becker, "Investment in Human Capital....," op. cit.
} 
their foregone earnings also leads to an underestimate, to the extent that some training costs are borne by firms. The calculation reported below is an estimate of foregone earnings of workers, using Census income data rather than firm accounting data. At least, in terms of population coverage, this is a complete calculation of what probably is the more important component of on-the-job training costs. The alternative procedure, of using firm data, is practically ruled out because of the meager supply of information, aside from the serious conceptual inadequacies. However, some attempt is made to supplement the estimates obtained from workers' income data with fragmentary estimates of firm costs.

A direct computation of foregone earnings of workers engaged in on-the-job training would be possible if data were available on their earnings during and after the period of training, and on earnings of a comparison group of workers who have the same amount of formal schooling and are otherwise similar to the trainees, but do not receive any onthe-job training. Presumably, the latter would have a flatter age-earnings profile than the former. That is, trainees would initially receive lower earnings than those not training, the difference representing costs of training. At a later age, earnings of trainees would rise above earnings of the untrained, the difference constituting a return on the investment. Unfortunately, it is impossible to classify workers empirically into such comparison groups. ${ }^{8}$ Given the group, say, of all male college graduates, there is no readily available statistic which would provide information on differential amounts of on-the-job training received by subgroups, and no income data are provided by such subclassifications. Even the fragmentary information on apprenticeships does not satisfy these requirements.

Fortunately, an alternative procedure based on Becker's theoretical analysis of investment in people $^{9}$ permits utilization of the comprehensive income data available in the United States Censuses. The procedure consists of a comparison of two average income streams of workers differing by levels of schooling, such as male college graduates and highschool graduates.

Taking this comparison as an example, the procedure involves year-by-year estimation of training costs which a highschool graduate must incur in order to acquire a college education and the ad-

${ }^{8}$ One interesting exception is the information obtained from an analysis of a sample of more than four hundred heads of households from the Consumer Union Panel, taken in 1959. The respondents were college-educated males who started on their first full-time job approximately twelve years before the survey date. The correlation between initial earnings of these individuals with their current earnings was used to test the existence of investment in on-the-job training by the predicted effects on age-earnings profiles:

Consider $Y_{t}$, the earnings of any individual at time $t$, as consisting of four additive components: $\bar{Y}_{t}$, average earnings of the group; $a_{t}$, an ability component of the individual; $c_{t}$, the investment component (a cost if negative, return if positive); and $u_{t}$, a random component.

$$
Y_{t}=\bar{Y}_{t}+a_{t}+c_{t}+u_{t} .
$$

For simplicity assume that the components are not correlated with one another, and $u$ is not correlated over time. Since $\bar{Y}_{t}$ is the same for all individuals in the group, the covariance between earnings in the first and the twelfth year is:

$\operatorname{Cov}\left(Y_{1}, Y_{12}\right)=\operatorname{Cov}\left(a+c+u_{1}, a_{12}\right.$

$\left.+c_{12}+u_{12}\right)=\operatorname{Cov}\left(a_{1}, a_{12}\right)+\operatorname{Cov}\left(c_{1}, c_{12}\right)$.

The correlation was found to be very close to zero. Since the covariance of the ability factor is surely positive (and roughly equal to the variance of the ability component of earnings), the second covariance must be negative and equally sizable. That is, the larger (more negative) the initially foregone earnings $\left(c_{1}\right)$, the larger (more positive) the return twelve years later $\left(c_{12}\right)$.

${ }^{9}$ Becker, "Investment in Human Capital ... .," op. cit. 
ditional amount of training on the job which is, on the average, characteristic of college graduates. Such estimates are obtained on the assumption that the rate of return is the same on each year's investment whether at school or on the job. ${ }^{10}$ In any given year $j$ after highschool graduation, those who go on to, or have graduated from, college would have earnings $\left(Y_{j}\right)$ which equal the earnings of high-school graduates $\left(X_{j}\right)$ plus the income earned on differential investment in training made since graduation from high school, provided no further investment in training was incurred by them during the year $\mathrm{j}$. Costs of (incremental) training in year $j$ are, therefore, measured by the difference between $Y_{j}$ and $X_{j}$ augmented by the (foregone) return on the previous (incremental) costs.

The procedure and the basic data utilized in it are shown in detail in the Appendix. The first step in the procedure is to compute the rate of return $(r)$ on the investment in training by which the two groups differ. This is done by equating the sum of discounted earnings differences to zero, after direct schooling outlays are netted out of earnings.

Once the rate of return is obtained, the comparison of net earnings streams $Y_{j}$ and $\mathrm{X}_{j}$ permits the following stepby-step calculation of training costs: let $j=1$ denote the first year of additional training. Then training costs in year 1 are $C_{1}=X_{1}-Y_{1}$, the observed income differential. In year 2 the costs are $C_{2}=$ $\left(X_{2}+r a_{1} C_{1}\right)-Y_{2}$, the observed income differential, augmented by the (foregone) return on previous costs. ${ }^{11}$ Proceeding sequentially, training costs in any year $j$ are

10 This assumption is later questioned. However, the fragmentary evidence in Sec. II below suggests that the assumption of equal rates is not unreasonable, when rates are computed on the sum of private and public costs of training.

$$
\begin{gathered}
C_{j}=X_{j}+\left(r \sum_{i=1}^{j-1} a_{i} C_{\imath}\right)-Y_{j} . \\
a i=\frac{1}{1-(1 / 1+r)^{n-i}},
\end{gathered}
$$

$a$ is a correction factor for finite life,,$^{12} n$ is the length of the working life.

Figures in Table 1 were computed in this fashion and cumulated over the working life. They constitute estimates of training costs: these are schooling costs before entry into the labor force and opportunity costs of on-the-job training afterward. The cumulation of annual costs over the working life stops at about fifteen to twenty years after entry into the labor force, since the computed training costs decline with age after laborforce entry and become negligible, fluctuating around zero, around age forty (see cols. [4], [5], and [6] in Appendix Tables A5-A7). The decline of training with age is consistent with a priori expectations about investment behavior: younger people have a greater incentive to invest in themselves than older ones,

${ }^{11}$ After a year of additional training, the income alternatives of the trainee are better than those indicated by the age profile $X_{j}$, which assumes no additional training.

12 The correction factor $a$ is not a sufficient correction for the effective length of the working life. Use of this factor alone assumes that all of a given cohort survive to a given age and have a 100 per cent labor force participation rate (after schooling) to this age. A complete correction should take into account mortality rates and the fraction of a cohort which is out of the labor force at each age. Adjustments for mortality and for labor-force participation were not incorporated in the estimating procedure. Neither have any significant effects on age-income profiles of males before the age of fifty. The effects on income differentials are small. According to Becker's work the mortality adjustment results in a small reduction of the rate of return, if the same mortality table is used for all education groups. The correction factor was used in the initial set of calculations, but discarded in the final revision, as it turned out to be negligible. Leaving out all these "survival" factors results in a small overstatement of costs, as is discussed later in the text. 
because they can collect the returns for a longer time. ${ }^{13}$

The age-earnings profiles which are the basic data used in deriving estimates of training costs are presented in Appendix Tables A1-A4. These are before tax incomes of United States males (wage and salary in 1939, income in 1949 and schooling enter the labor force at age fourteen and have no foregone earnings while at school; high-school graduates enter the labor force at age eighteen, and their foregone earnings during highschool attendance are obtainable by comparison with incomes of elementaryschool graduates of the same age; college

TABLE 1

Lifetime Investment in Training Per Capita at School and On-The-Job, United States Males, 1939, 1949, 1958, BY Level OF Schooling

(In Thousands)

\begin{tabular}{|c|c|c|c|c|c|c|c|c|c|c|c|c|}
\hline \multirow{3}{*}{ Educational LEVEL } & \multicolumn{6}{|c|}{ Current Dollars } & \multicolumn{6}{|c|}{1954 DoLlars* } \\
\hline & \multicolumn{3}{|c|}{ Marginal Cost } & \multicolumn{3}{|c|}{ Total Cost } & \multicolumn{3}{|c|}{ Marginal Cost } & \multicolumn{3}{|c|}{ Total Cost } \\
\hline & $\begin{array}{c}\text { School } \\
\text { (1) }\end{array}$ & $\begin{array}{l}\text { On-the- } \\
\text { Job } \\
(2)\end{array}$ & $\begin{array}{l}\text { Sum } \\
(3)\end{array}$ & $\begin{array}{c}\text { School } \\
(4)\end{array}$ & $\begin{array}{l}\text { On-the- } \\
\text { Job } \\
\text { (5) }\end{array}$ & $\begin{array}{l}\text { Sum } \\
(6)\end{array}$ & $\begin{array}{c}\text { School } \\
(1)\end{array}$ & $\begin{array}{l}\text { On-the- } \\
\text { Job } \\
(2)\end{array}$ & $\begin{array}{l}\text { Sum } \\
(3)\end{array}$ & $\begin{array}{c}\text { School } \\
(4)\end{array}$ & $\begin{array}{c}\text { On-the- } \\
\text { Job } \\
(5)\end{array}$ & $\begin{array}{r}\text { Sum } \\
(6)\end{array}$ \\
\hline $\begin{array}{l}\text { 1939: } \\
\text { Colleg }\end{array}$ & 4 & & & & & & & & & & & \\
\hline High school. & 2.0 & 2.4 & $\begin{array}{l}0.4 \\
4.4\end{array}$ & 2.8 & 4.4 & $\begin{array}{r}10.0 \\
7.2\end{array}$ & 3.9 & $\begin{array}{l}0.6 \\
4.6\end{array}$ & $\begin{array}{r}10.2 \\
8.5\end{array}$ & 5.2 & 8.5 & $\begin{array}{l}29.9 \\
13.7\end{array}$ \\
\hline $\begin{array}{l}\text { Elementary } \\
\text { school.... } \\
\text { 1949: }\end{array}$ & .8 & 2.0 & 2.8 & .8 & 2.0 & 2.8 & 1.3 & 3.9 & 5.2 & 1.3 & 3.9 & 5.2 \\
\hline $\begin{array}{l}\text { College.... } \\
\text { High school }\end{array}$ & 10.2 & $\begin{array}{r}15.7 \\
4.7\end{array}$ & $\begin{array}{r}25.9 \\
8.8\end{array}$ & 15.9 & 24.3 & 40.2 & 11.5 & 17.7 & 29.3 & 18.0 & 27.4 & 45.4 \\
\hline $\begin{array}{l}\text { Elementary } \\
\text { school. . } \\
\text { 1958: }\end{array}$ & 1.6 & 3.9 & 5.5 & 1.6 & 3.9 & 5.5 & 1.8 & 4.4 & $\begin{array}{l}9.9 \\
6.2\end{array}$ & 1.8 & 4.4 & 6.2 \\
\hline College & 16.4 & 22.5 & 38.9 & 26.0 & 30.7 & 56.7 & 15.3 & 21.2 & 36.5 & 24.1 & 28.8 & 52.9 \\
\hline $\begin{array}{l}\text { High school... } \\
\text { Elementary }\end{array}$ & 71 & 2.9 & 10.0 & 9.5 & 8.2 & 17.7 & 6.6 & 2.7 & 9.3 & 8.8 & 7.6 & 16.4 \\
\hline schoo & 2.4 & 5.3 & 7.7 & 2.4 & 5.3 & 7.7 & 2.2 & 4.9 & 7.1 & 2.2 & 4.9 & 7.1 \\
\hline
\end{tabular}

Source: Appendix Tables A1-A7.

* Deflated by the Bureau of Labor Statistics' Consumer Price Index.

in 1958), classified by age and education, and adjusted to approximate the relevant concepts. The adjustments involve netting out direct school costs and corrections for part-time employment of students during the period of school attendance. For these purposes, and in order to separate school and on-the-job training costs, the assumption was made that people with none up to eight years of

\footnotetext{
${ }^{13}$ Becker, "Investment in Human Capital . . .," op. cit.
}

students graduate at ages twenty-two to twenty-three, and estimates of relevant income differentials are constructed in a similar way.

For each date and education group, year-by-year estimates of marginal costs of training were calculated by equation (1). An illustrative calculation is shown in Appendix Table A4. Detailed annual figures are shown in Tables A5-A7, columns (1), (2), and (3). The annual estimates of marginal costs are then cumu- 
lated horizontally in columns (4), (5), and (6) of Tables A5-A7, to obtain annual total costs of schooling and of onthe-job training. Summing the figures in each column yields, separately, lifetime total costs of schooling and of on-the-job training typical of groups with given levels of schooling per person. The results are presented in Table 1 .

In reading this table it is important to distinguish between the "marginal" and "total" figures. The costs of attending high school, shown as marginal costs of high-school education, do not measure the total costs of schooling of the individual up to and including high school. For this purpose the costs of high-school attendance must be added to the costs of elementary-school attendance. Similarly, the costs of on-the-job training of a highschool graduate as obtained by equation (1) are additional costs over and above the costs of on-the-job training incurred by elementary-school graduates. These marginal costs (col. [2] in Table 1) are first differences of the total costs of onthe-job training for graduates of any particular level of schooling, shown in column (5) of Table 1.

The estimates of on-the-job training costs in Table 1 are per capita magnitudes approximating the sum of resources the average male of a given educational level may be expected to invest in training on the job during his working life. Estimates of the aggregate investment by male workers in the economy during a given year are shown in Table 2. They are obtained by multiplying the year-by-year costs of training, as shown in Tables A5-A7 (cols. [4], [5], and [6]), by the number of workers ${ }^{14}$ (student enrolment during the period of schooling) in the corresponding age and educational group (cols. [7], [8], and [9]). The crossproducts are then summed to obtain ag- gregate costs corresponding to the total cost classifications in Table 1 , columns (3), (4), and (5).

In contrast to Table 1, Table 2 represents actual opportunity costs in the economy, not expectations of individuals. The relative sizes of the two components of training costs, formal and on the job, are also different in the two tables. This is because the aggregative estimates in Table 2 depend on the age distribution of workers with given levels of educational attainment. Secular trends in population size and in educational attainments affect the relevant age distributions in a way which makes the aggregative onthe-job training costs somewhat smaller in relation to school costs than is true on the per capita basis.

Before proceeding to discussion and interpretation of the findings one must raise questions about their validity and reliability. A number of possible sources of bias are easily identified. First, the estimates of per capita training costs (Table 1) are based on cross-section income profiles. They, therefore, may approximate expectations of an average male of a given educational level, provided the differences between his earnings and earnings of males at the next lower educational level will change year after year in the future, precisely the way they do change in the cross-sectional comparison from one cohort to the next, one year older. If secular trends are expected to tilt both income streams upward by the same percentage, the returns (income differentials at a later stage of life) are likely to increase somewhat, with

${ }^{14}$ To obtain estimates of investments by all workers, those with "some elementary schooling," "some high school," and "some college" have to be included in the calculation. It was assumed that their investment costs are halfway between investment costs of graduates at neighboring educational levels. See notes to Appendix Tables A5-A7. 
income differentials at an early stage largely unaffected. On this assumption, the procedure involves a small underestimate of the rate of return since differentials later in life are heavily discounted. In turn, this implies an understatement of costs, to the extent that costs are, in part, a positive function of the discount rate (eq. [1]). served cross-sectional age-income profiles are biased downward at older ages in all educational groups except the lowest. The failure to tilt the income streams upward leads, as before, to an understatement of costs, mainly at the upper levels of education.

For another reason, costs were underestimated also at the lower levels of edu-

TABLE 2

Aggregate AnNual Investment in Training at School and On-the-Job, United States Males, 1939, 1949, 1958, By Level OF Schooling

(In $\$$ Billions)

\begin{tabular}{|c|c|c|c|c|c|c|c|c|c|}
\hline \multirow{2}{*}{ Educational Level } & \multicolumn{3}{|c|}{1939} & \multicolumn{3}{|c|}{1949} & \multicolumn{3}{|c|}{1958} \\
\hline & School & Job & Total & School & Job & Total & School & Job & Total \\
\hline & \multicolumn{9}{|c|}{ Current Dollars } \\
\hline $\begin{array}{l}\text { College ........... } \\
\text { High school...... } \\
\text { Elementary ...... }\end{array}$ & $\begin{array}{r}1.1 \\
1.8 \\
.9\end{array}$ & $\begin{array}{r}1.0 \\
1.4 \\
.6\end{array}$ & $\begin{array}{l}2.1 \\
3.2 \\
1.5\end{array}$ & $\begin{array}{l}3.8 \\
3.4 \\
2.1\end{array}$ & $\begin{array}{r}4.3 \\
3.8 \\
.9\end{array}$ & $\begin{array}{l}8.1 \\
7.2 \\
3.0\end{array}$ & $\begin{array}{l}8.7 \\
8.4 \\
4.5\end{array}$ & $\begin{array}{l}8.7 \\
3.8 \\
1.0\end{array}$ & $\begin{array}{r}17.4 \\
12.2 \\
5.5\end{array}$ \\
\hline \multirow[t]{2}{*}{ All levels. } & 3.8 & 3.0 & 6.8 & 9.3 & 9.0 & 18.3 & 21.6 & 13.5 & 35.1 \\
\hline & \multicolumn{9}{|c|}{1954 Dollars } \\
\hline $\begin{array}{l}\text { College...... } \\
\text { High school. } \\
\text { Elementary.. }\end{array}$ & $\begin{array}{l}2.1 \\
3.5 \\
1.9\end{array}$ & $\begin{array}{l}1.9 \\
2.7 \\
1.1\end{array}$ & $\begin{array}{l}4.0 \\
6.2 \\
2.8\end{array}$ & $\begin{array}{l}4.3 \\
3.8 \\
2.4\end{array}$ & $\begin{array}{l}4.7 \\
4.2 \\
1.0\end{array}$ & $\begin{array}{l}9.0 \\
8.0 \\
3.4\end{array}$ & $\begin{array}{l}8.1 \\
7.8 \\
4.2\end{array}$ & $\begin{array}{r}8.1 \\
3.5 \\
.9\end{array}$ & $\begin{array}{r}16.2 \\
11.3 \\
5.1\end{array}$ \\
\hline All levels... & 7.3 & 5.7 & 13.0 & 10.5 & 9.9 & 20.4 & 20.1 & 12.5 & 32.6 \\
\hline
\end{tabular}

Source: Appendix Tables A1-A7.

Another bias is introduced by using the cross-sectional patterns as approximations for the true earnings streams. This is the misreporting of years of schooling by Census respondents. According to Denison, the older the group in an education class, the larger the fraction of persons reporting a level of education higher than the one they reported at the previous Census. ${ }^{15}$ This means that ob-

${ }^{15}$ E. F. Denison, "A Note on Education, Economic Growth, and Gaps in Information," in this Supplement. cation. I compared the earnings stream of elementary-school graduates with that of persons with one to four years of schooling rather than with persons with zero schooling. The group with no schooling is small, and its composition so different from that of the other groups (it is heavily weighted with farm workers, single persons, and non-whites) that its age-earnings profile could not serve as a bench mark. To the extent that persons with zero to four years of schooling undergo some on-the-job training, which 
is undoubtedly true, the costs of such training have been omitted from my estimates.

An opposite bias is imparted by omission of the survival factors, as mentioned previously (n. 12). Lack of adjustment for mortality, for example, means that earnings differentials at later ages are overstated. Costs are therefore overestimated, because the rate of return is overestimated, though by a small amount.

The 1949 and 1958 income figures include property income in addition to labor income, and this too tends to widen differentials between profiles noticeably at later ages. This is because of a positive correlation of property income with age and with education. The result is a slight overestimate of costs by an overestimate of the rate of return.

A more serious question is posed by the assumption that differences in income streams of the groups compared are attributable to differences in training. Such an assumption disregards other factors which may affect shapes and levels of age profiles. Biases will arise if these other factors are not independent of the classificatory criteria: for example, the higher the years of schooling and the higher the age, the lower the fraction of males who are non-white. Farmers and farm laborers are disproportionately distributed in the low years of schooling and low age classes. Restriction of estimates to non-farm whites (as in 1939) avoids the distortions, but such data were not available for all the periods. It is clear, however, that, even in data which are quite homogeneous by Census criteria, certain selective or restrictive factors are not neutral with respect to the educational classification: people who undertake more training are likely to have higher intelligence quotients, higher parental income and education, more motivation and information.
The extent to which earnings of more trained persons exceed earnings of less trained persons is, therefore, an overestimate of the return on training. Part of the observed return is a return to these "ability" factors. But, for the same reasons, the observed data are likely to underestimate the costs incurred: if more capable high-school students enter college, their foregone earnings are probably underestimated by the observed earnings of the less capable high-school graduates who did not go on to college. It is difficult to say, a priori, how large such biases may be. But, if a correction for the "ability" factor involves a decrease in return and a simultaneous increase in cost via income differentials, it is clear that the relative decline in the rate of return must be larger than the relative increase in costs. ${ }^{16}$ According to Becker an adjustment for class standing of highschool graduates brings the rate of return down by about 15 per cent. If costs are underestimated, this figure measures the maximum amount of bias, when the dimension of ability which is measured by class standing is taken into account. Other factors may account for more.

Once again, the bias need not be in one direction. To the extent that the restrictive factors under discussion affect returns (earnings differentials after the training period) without affecting income differentials during the training period, the rate of return and costs are overestimated. This is because costs, as we computed them, are in part a positive function of the rate of return.

Possibly the largest source of downward bias in the estimation of costs was already mentioned: the omission of costs

${ }^{16}$ The rate of return is a ratio of returns to costs, $r=k / c$. If only $c$ were increased, with $k$ left the same, the relative (per cent) decrease in $r$ would equal the relative increase in $c$. But, since $k$ is decreased, the relative decrease in $r$ is stronger than the relative increase in $c$. 
of training which are borne by firms. These costs do not show up in the income data at all. As a simple example, take the case of a firm which pays half the costs of training, the other half being paid by the worker. Later on, the firm captures half of the returns. Rates of return are not affected, and foregone earnings of workers are cut in half.

It is not possible to arrive at an overall notion of the direction of bias without knowing more about the magnitudes of each possible error. But, if there is some reason to believe that totals are underestimated, there are reasons to believe that the distortion is weaker when it comes to relative sizes of subtotals in the classifications of Tables 1 and 2. If ability factors bias costs in the comparison of college and high school, they have similar effects in the high school and elementary school.

The striking finding in Table 1 is that the opportunity costs of on-the-job training per male are almost without exception somewhat higher than costs of a comparable increment of schooling. But while per capita amounts of formal schooling (as measured by costs in constant dollars) grew between 1939 and 1958 at all levels, the corresponding quantities of on-the-job training per capita grew mainly at the higher educational levels.

On an aggregative basis (Table 2) onthe-job training costs were a little smaller than schooling costs in 1939 and grew at a slower rate than the former. Formal education expenditures grew rapidly at all levels during the 1939-58 period. Onthe-job training expenditures grew just as fast as schooling at the highest educational level, increased before 1949 and decreased afterward at the high-school level, and continuously declined at the elementary-school level. The per capita figures (Table 1) indicate, however, that the decline in aggregate on-the-job training for the elementary-school class was not a result of a decline in costs per head but a decline in the number of heads. Similarly, the increase in on-the-job costs in the aggregate for the college class also consisted mainly in an increase in the number of heads rather than in training costs per head, particularly in the second decade.

One feature of the findings in Table 1 is worthy of closer attention: on-the-job training is a larger quantity the higher the level of education. This is not a truism as in the case of schooling, where the marginal quantities of schooling are positive by definition. There is nothing in the calculation of on-the-job training costs that would make the marginal quantities necessarily positive. In other words, the positive association between school training and on-the-job training is not definitional; it is an empirical inference from the observed income data. More training seems to involve more of both forms of training, though not in any fixed proportion. This is reasonable: school education is a prerequisite, a basis on which to build the further, more specialized training.

Some independent evidence on this positive association is provided by recent Department of Labor estimates of amounts of school and on-the-job training, both measured in school-grade equivalents, required for the acquisition of occupational skill in four thousand detailed occupations. ${ }^{17}$ From the four thousand occupations listed in the publication, a sample of 158 occupations was selected on the basis of comparability with the 1950 Census occupational break-

${ }^{17}$ United States Department of Labor, Bureau of Employment Security, United States Employment Service, Estimates of Worker Trait Requirements for 4,000 Jobs as Defined in the Dictionary of Occupa. tional Titles (Washington, 1956). 
down. The two measures of school and on-the-job training requirements given in rank form, were correlated with coefficient +.86 .

The positive association between schooling and on-the-job training helps in understanding trends. It suggests that an expansion of education is likely to bring about an expansion of on-the-job training, a development indicated in Tables 1 and 2. To the extent that an expansion of education is induced by a decrease in its price relative to the price of on-the-job training, some substitution will take place, and education may grow at the expense of on-the-job training. Such factors, among others, may underlie the slower growth of on-the-job training than of schooling. More precisely, the data suggest slow or no growth of onthe-job training at the lower educational levels and pronounced growth at upper educational levels. This finding supports popular impressions about the changing levels of on-the-job training: a shift from apprenticeships to technicians, scientific personnel, and executive development programs. Such shifts may, in the aggregate, reflect the upward trend in supplies of labor with high levels of educational attainment and possibly some substitution phenomena at the lower levels. The questions about trends are very intriguing, but the data do not lend themselves to more than conjectures.

Turning to bodies of data other than the comprehensive income statistics, I tried to exploit them, though not very intensively, for two purposes: (1) to provide some empirical checks on the reliability of estimates based on foregone incomes of workers, (2) to form some guesses about firm costs or outlays.

1. On the basis of the BLS publication on skill requirements for 4,000 occupations, Eckaus estimated the average number of college-equivalent years of on-the-job training imbedded in the labor force (including females). ${ }^{18}$ The estimate was 1.66 and 1.72 for 1939 and 1949 , respectively. But these are average quantities for the whole age distribution, figures representing a stock. We are interested in the flow of current investment in on-the-job training, and this is incurred mainly by the younger age groups. These groups have higher education levels than the labor force as a whole and are, therefore, likely to invest more also in on-thejob training. In 1949 the age group 18-29 had a median schooling of 12 years compared to a labor force median of 10 years. The discrepancy between means was even greater. Since the investment in onthe-job training is higher at higher educational levels, an upward adjustment is required. Using the ratio of medians to revise Eckaus' estimates upward, roughly in proportion, yields 1.99 and 2.06 years for 1939 and 1949 respectively.

In terms of equivalent college costs per year, 2.06 years of training would cost about $\$ 6,000$ per member of the labor force in 1950, according to Table 1 . The average female invests in on-the-job training about one-tenth as much as the average male, ${ }^{19}$ and the number of females was slightly over a third of the total labor force in the age group 18-29. Hence, the implicit cost $(C)$ on-the-job training incurred per male in 1949 is:

$$
\begin{aligned}
\$ 5,200 & =\frac{2}{3} C+\frac{1}{30} C \\
C & =\$ 7,500 .
\end{aligned}
$$

${ }^{18}$ R. S. Eckaus, "Education and Economic Growth," in Economics of Higher Education, ed. Selma J. Mushkin (Washington: United States Department of Health, Education, and Welfare [forthcoming]), Tables 1 and 2. College equivalence is implied in United States Department of Labor, Bureau of Employment Security, United States Employment Service, op. cit., p. 111.

${ }^{19}$ See Part III below. 
This compares with our estimates of $\$ 8.600$ costs of on-the-job training of male high-school graduates (Table 1, col. [5]), the modal group in the population. A similar calculation for 1939 yields about $\$ 3,600$ to be compared with our estimate $\$ 4,400$. Elements of subjectivity in the BLS-derived figures make the comparison difficult, but the fact that the two sets of estimates are not very far apart is encouraging.

Another piece of supplementary evidence is provided by data on the distri- is understandable in view of differences in age and in educational backgrounds already acquired.

2. Several recent surveys of training activities in firms have shown that such functions are carried by many firms. ${ }^{20}$ Of course, only formally arranged programs are described in such surveys. Unfortunately, questions about costs are seldom raised in these surveys. Undoubtedly, it would be difficult to interpret the financial data, even if they were forthcoming. In only one of the recent studies

TABLE 3

GI Bill Expenditures, By Level and Type of Training, 1945-55

\begin{tabular}{|c|c|c|c|c|c|}
\hline \multirow{2}{*}{ Level of Training } & \multirow{2}{*}{$\begin{array}{c}\text { No. of } \\
\text { Veterans } \\
\text { (Millions) } \\
\text { (1) }\end{array}$} & \multicolumn{2}{|c|}{ GI Bill Expenditures } & \multicolumn{2}{|c|}{$\begin{array}{c}\text { All Males, Aggregates } \\
\text { For } 1949\end{array}$} \\
\hline & & $\underset{(2)}{\$ \text { Billions }}$ & $\begin{array}{l}\text { Per cent } \\
\quad(3)\end{array}$ & $\underset{(4)}{\$ \text { Billions }}$ & $\begin{array}{l}\text { Per cent } \\
\quad(5)\end{array}$ \\
\hline $\begin{array}{l}\text { College .......... } \\
\text { High school..... } \\
\text { Trade school..... } \\
\text { On the job...... }\end{array}$ & $\begin{array}{l}2.2 \\
1.4 \\
2.1 \\
2.1\end{array}$ & $\begin{array}{l}5.5 \\
2.2 \\
3.3 \\
3.5\end{array}$ & $\begin{array}{l}38.1 \\
15.3 \\
23.1 \\
24.5\end{array}$ & $\begin{array}{l}4.5 \\
3.3\end{array}$ & $\begin{array}{l}40.8 \\
30.0 \\
29.2\end{array}$ \\
\hline Total. & 7.8 & 14.5 & 100.0 & 11.0 & 100.0 \\
\hline
\end{tabular}

Source: Cols. (1) and (2), President's Commission on Veterans' Pensions, Readjustment Benefits, Staff Report (No. IX, Part B [Washington: Government Printing Office, September 12, 1956]), pp. $22-24,30-32$.

bution of federal expenditures on the GI Bill for 1945-55. The expenditures and their distribution are given in Table 3. In columns (3) and (5) we compare the percentage distributions of expenditures: costs of college training of veterans during the ten-year period are compared with costs of college of all males in 1949; a similar comparison of veterans' costs is made with marginal costs of high school, and with total costs of on-the-job training of high-school graduates. The distributions (col. [3] and col. [5]) look reasonably comparable. The greater selectivity of veterans toward college and vocational training (trade schools and on the job) in comparison to all males were such questions asked, with these results:

Although questions were asked concerning total expenditures for in-company education, few firms replied-Perhaps the chief reason was that often the books of the firm were not kept in a manner that would make it easy to separate educational costs from other costs. Other reasons centered around questions of allocation and items to be considered as costs-The data reported are not comparable, since some of the figures include salaries and some exclude them. It is not certain that the figures reported include all in-company programs. In one case it was specifically stated that the figure reported was for one program..$^{21}$

${ }^{20}$ Clark and Sloan, op. cit., Serbein, op. cit., and the 1960 New Jersey Survey of the Bureau of Apprenticeships and Training.

${ }^{21}$ Serbein, op. cit., pp. 9-10. 
If the scant financial replies shown in this survey are blown up to an aggregate, the result is an estimate below $\$ 1$ billion for 1957, undoubtedly a severe underestimate of even those current firm outlays which are easily identifiable. Smaller case studies indicate that firm expenditures on formal training programs must be much larger: estimates range from $\$ 85$ for an operative in training ${ }^{22}$ to over $\$ 10,000$ for an executive training program. ${ }^{23}$ According to the recent comprehensive survey of New Jersey industries made by the Bureau of Apprenticeship and Training, ${ }^{24}$ the proportion of workers participating in formal training programs in 1959 was about 5 per cent. Of these 20 per cent enrolled in management development programs, 10 per cent in apprenticeships, 10 per cent in technical (semiprofessional) training, 12 per cent in sales training, and the rest in short programs of operative training, orientation, safety, etc. Applying almost any vaguely reasonable dollar figuresfrom $\$ 85$ per operative to a conservative $\$ 2,000$ per executive trainee per annum, and projecting to the aggregate labor force in recent years, yields an estimate of $\$ 2-\$ 3$ billion. But this, of course, misses all costs incurred in informal training, which is the typical situation: only 16.2 per cent of firms in New Jersey had formal training programs.

One estimate which takes into account "invisible" costs of firms, including costs in informal training processes, can be obtained using figures shown in a recent study of California firms by the American Management Association. ${ }^{25}$ In this

22 "Training Manpower," Fortune, July, 1951.

${ }^{23}$ Clark and Sloan, op. cit., p. 3.

${ }^{24}$ See references cited in n. 2.

${ }^{25}$ Merchants and Manufacturers Association, Labor Turnover: Causes, Costs and Methods of Control (New York, February, 1959). study estimates were made of costs of labor turnover to the firm. The concept of replacement cost includes hiring costs such as advertising, recruitment, interviews, and separation costs; on-the-job training costs are defined more comprehensively as "the expense brought about by sub-standard production of new employees while learning their job assignments and becoming adjusted to their work environment; the dollar value of time spent by supervisors and other employees who assist in breaking in new employees on their job assignment, and costs of organized training programs." ${ }^{26}$ These training costs per worker replacement were estimated at about $\$ 230$. If hiring and separation costs are included the figure doubles. Multiplying these costs of a replacement by the total number of replacements in industry in $1958^{27}$ yields an estimate of $\$ 7$ billion. Inclusion of hiring and separation costs raises the estimate to $\$ 14$ billion. The assumption that all of these costs are borne by the firms is, of course, highly questionable. How much is shifted back to the trainee in the form of a wage reduction is not known. At the same time, a large part of the opportunity cost of workers-the difference between what they did produce while in training and what they could produce if they did not train-is also missed in these figures.

All these heroic attempts to estimate firm costs add up to an uncomfortable range of uncertainty when it comes to answering the question: how much of firm costs should be added to the estimates of foregone incomes of workers? It is possible that billions of dollars are involved, but it is not clear how many.

Besides firm costs, two more items

${ }^{26}$ Ibid.

${ }^{27}$ About thirty million, using the observed average monthly replacement rate of 4 per cent. 
must be added to our estimates in Table 2 to get total costs of on-the-job training in the economy: training costs incurred by women and training expenditures in the Armed Forces. The latter are estimated at $\$ 1.6$ billion $^{28}$ in 1959 , and the former at $\$ 1.4$ billion $^{29}$ in 1958 . According to Table 2, aggregate opportunity costs of male workers were about $\$ 13.5$ billion in 1958. Addition of the two items brings the figure up to $\$ 16.5$ billion, more than half of the aggregate costs of schooling (males and females) in $1956 .{ }^{30}$ The addition of possibly several billion dollars of costs borne by firms narrows the difference but may not close it. Since most of the on-the-job training costs are incurred by and spent on male workers, it is probably correct to say that, in the male half of the world, on-the-job training-measured in dollar costs-is as important as formal schooling.

\section{ESTIMATES OF RATES OF RETURN}

An estimate of rates of return to onthe-job training is both desirable and difficult to obtain. The rate of return computed by equating the present values of net earnings of two education groups should not be interpreted as a rate of return on schooling costs. The computed rate is some average of rates of return to schooling and to on-the-job training. The hybrid rate depends on the weights (costs) of the two training components and on the rates on each component. ${ }^{31}$ If the rate on one component is known, the

\footnotetext{
${ }^{28}$ Includes military schools and graining programs but excludes basic training and depreciation of equipment (estimated by R. C. Blitz in "The Nations Educational Outlay," in Mushkin (ed.), Economics of Higher Education.

${ }^{29}$ Based on 1949 estimates for female college graduates (see Part III, below).

${ }^{30}$ According to Schultz, the total cost of schooling was $\$ 28.7$ billion in 1956 ("Investment in Human Capital," op. cit.).
}

other can be approximated in a residual fashion. What is immediately important, the larger the difference between the rates of return on investment in schooling and in on-the-job training, the less accurate are the cost estimates in the preceding section, as well as the various recent estimates of rates of return on (school) education. If the rate of return on schooling exceeds the rate on on-thejob training, the estimates are on the low side.

It is not obvious, on a priori grounds, whether the money rate of return to onthe-job training is likely to be smaller or larger than the rate on formal education. It could be argued that non-pecuniary, "consumption" elements may be a more important part of the real return to formal education then to on-the-job training. If so, and if this were the only difference, the money rate of return on schooling would appear smaller than the rate to on-the-job training. Larger public subsidies to formal education would also have this effect, if returns are computed on total costs (private and public). These arguments are based on an assumption of equality of the real (pecuniary and non-pecuniary) private rate of return in both training sectors.

One could argue, however, that larger impediments to a flow of investment into formal education make for higher rates of return to schooling than to on-the-job training. Income constraints are less severe in the latter case as costs are more spread out over time. Perhaps more important is that this investment is undertaken at a later age and in the context of a concrete, existing work situation: there is much less uncertainty about future

${ }^{31}$ It also depends on timing. The chronologically earlier component receives greater weight (see Becker, "Investment in Human Capital ...," $o p$. cit.). 
prospects, about one's own abilities and motivations, etc. These circumstances tend to produce a lower real rate of return to on-the-job training and may well reduce the money rate on it to a lower level than the money rate on formal education.

There are no comprehensive data comparable to the Census classifications by formal education level from which to compute rates to on-the-job training. The rates shown in Table 4 were estimated for a few selected skills for which

TABLE 4

\section{RATES OF RETURN ON APPRENTICESHIP \\ Training, Selected Trades, 1949}

\begin{tabular}{|c|c|c|c|}
\hline \multirow[b]{2}{*}{ Trades } & \multicolumn{3}{|c|}{$\begin{array}{l}\text { Assumptions about Alternative } \\
\text { In CoMe Streams }\end{array}$} \\
\hline & $\begin{array}{l}\text { Operatives } \\
\text { in Same } \\
\text { Industries } \\
\text { (1) }\end{array}$ & $\begin{array}{c}\text { Operatives } \\
\text { with } \\
\text { Highest } \\
\text { Schooling } \\
\text { (2) }\end{array}$ & $\begin{array}{c}\text { Assuming a } \\
10 \text { Per Cent } \\
\text { Return on } \\
\text { Additional } \\
\text { Schooling } \\
\text { (3) }\end{array}$ \\
\hline $\begin{array}{l}\text { Metal.... } \\
\text { Printing. } \\
\text { Building. }\end{array}$ & $\begin{array}{l}16.4 \\
16.0 \\
18.3\end{array}$ & $\begin{array}{l}10.4 \\
12.6 \\
11.3\end{array}$ & $\begin{array}{l}9.5 \\
9.0 \\
9.7\end{array}$ \\
\hline
\end{tabular}

Source: Table A8

tolerably good data are available. These refer to apprenticeship training in the several industries in which they are concentrated. All estimates are for 1949.

The rates of return on apprenticeship training were computed in three different ways providing a range of estimates, from the highest values in column (1) to the lowest in column (3) of Table 4. However, the lowest values (col. [3]) are conceptually the soundest. The computations involve equating to zero the present value of differentials between earnings of workers who served an apprenticeship and earnings of their assumed alternative occupational groups. During the period of training the apprentice receives an average wage $W_{a}$, after which he becomes a journeyman receiving an average wage $W_{m}$. A suitable alternative occupation, ${ }^{32}$ where almost no training is involved, is the operative, and his average wage is $W_{o}$. The annual wage differential $d=W_{a}-W_{o}$ is negative during the training period and positive afterward, $k=W_{m}-W_{o}$ assumed constant for the rest of the working life. Under these assumptions, and disregarding a negligible correction for the finiteness of working life, the rate of return $(r)$ is easily obtained from: $:^{33}$

$$
(1+r)^{n}=1+\frac{k}{d}
$$

where $n$ is the number of years of training, or length of the apprenticeship.

Estimates in column (1) of Table 4 are based on comparisons of earnings of apprentices, journeymen, and operatives in the same industries. While operatives and corresponding craftsmen had the same median schooling, the apprentices had two to three more years of schooling than the other two groups in 1949. Thus $k$, the difference between earnings of journeymen and operatives, is computed correctly, holding formal schooling the same. But foregone earnings of apprentices are underestimated: having more schooling than the operatives with whom they are compared, the apprentices could earn more in alternative jobs. With returns correct and costs underestimated, figures in column (1) are too high.

32 This occupation is more appropriate as an alternative, in terms of educational background, than laborers. Clerical work is an alternative, but it probably contains more on-the-job training than operative jobs, which involve at most a few months of training.

$$
d \cdot \sum_{i=1}^{n} \frac{1}{(1+r)^{i}}=k \cdot \sum_{j=n+1} \frac{1}{(1+r)^{i}} .
$$

The assumption of infinite life creates a negligible error. 
In column (2) this defect is corrected to a large extent. In the calculation, $k$ is the same as before, but $d$ was computed from a comparison of wages of apprentices with wages of operatives whose schooling levels are closer to levels of apprentices, regardless of industry attachment. As Table A8 shows, however, median schooling of these operatives is still about a year less than of apprentices, so rates may still be overestimated.

In column (3) the same $k$ is used again, but the opportunity cost is computed by adding to $d$ (as computed in col. [1]) a return on additional years of (high-school) education ${ }^{34}$ by which apprentices exceed the operatives with whom they are compared in column (1). This brings the rates down to the levels shown in column (3).

The estimates probably suffer from several biases. Operatives have some onthe-job training, but so do craftsmen after completion of apprenticeships. If the additional training of the latter exceeds that of the former, the rates of return on apprenticeships are overestimated. On the other hand, abstraction from secular rates of growth, as in the general case, ${ }^{35}$ may have the opposite effect. It is also possible that union restrictions on entry to apprenticeships resulted in higher returns in the several fields selected in Table 4 than in other kinds of 'on-the-job training. ${ }^{36}$

For a comparison with another high level of skill, I computed rates of return on medical specialization, comparing incomes of residents and specialists (after residency) with incomes of general prac-

${ }^{34}$ A 10 per cent rate was used. Higher rates would lower the figures in col. (3) even more.

${ }^{35}$ See Part I, above.

${ }^{36}$ However, according to a recent study by H. G. Lewis, the impact of unionism on wage differentials was very small in the 1945-50 period ("Union Effects on Relative Wages," in Aspects of Labor Economics [National Bureau of Economic Research Conference, 1960 (New York, 1960)]). titioners. The computation utilizes ageincome profiles of independent medical specialists, starting with an initial period of residency, with the income profile of independent general practitioners, starting with the first year in practice. Estimates of income in money and kind of residents were obtained from American Medical Association sources; ${ }^{37}$ earnings from 1950 Census sources. ${ }^{38}$ The calculation on before-tax incomes showed a return of 12.7 per cent. A rough adjustment for taxes brought the rate down to 11.3 per cent. It is difficult to judge whether this is high or low in comparison with apprenticeships. ${ }^{39}$

Table 5 compares estimated rates of return on apprenticeships and on training at the college level.

Generalizing boldly, a comparison of columns (1) and (2) suggests that money rates of return (before tax) on total costs (public and private) are similar for school and on-the-job training. Figures in col-

${ }^{37}$ Journal of the American Medical Association, September 22, 1956, pp. 277 ff., and October 10, 1959 , pp. 665 ff.

38 "Income of Physicians," Survey of Current Business, July, 1951.

${ }^{39}$ The 1950 rate of return to medical specialization may have been above equilibrium. The proportion of specialists among physicians was less than half in 1950 and increased to about two-thirds by 1960 (according to Medical Economics, 1961). If this was a supply shift in response to a high level of demand, the rate of return on specialization should be less today than in 1950. Data from medical sources (Physicians Earnings and Expenses, published by Medical Economics, 1961) indicate that in 1959 the money income differential between specialists and general practitioners is no larger than it was in 1949 , despite the fact that the average incomes of specialists rose over 60 per cent during the period, residencies lengthened somewhat, and opportunity costs clearly increased. If the data are reliable, it would seem that rates of return today are a few percentage points lower than in 1949. Incidentally, estimates of rates of return on specialization in medicine have little bearing on the question of alleged monopoly returns in medicine. Whatever the barriers to entry into medicine, once a medical degree was obtained, institutional obstacles to specialization are weak. 
umn 1 are weighted averages of returns on the two sectors; similarity of average and component means that rates on each component are alike. It does appear, however, that private rates of return are lower for the selected instances of onthe-job training than for total training at college levels. If the selected instances can be generalized, the rate of return on college education per se is somewhat underestimated by the figures in column (1). Apparently, the greater ease of investing in on-the-job training outweighs

TABLE 5

RETURNS TO "EDUCATION" AND TO ON-THEJOB TRAINING, 1950

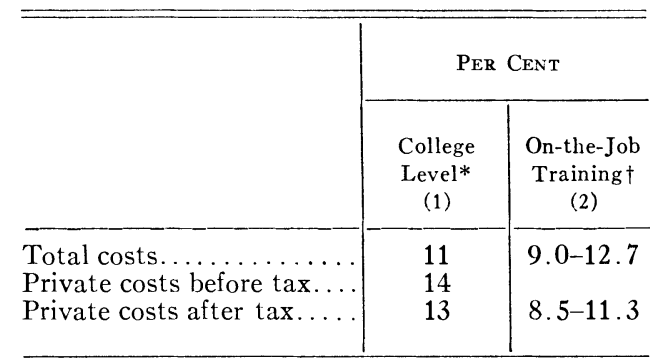

* Source: G. S. Becker, "Underinvestment in College Education?" op. cit.

$\dagger$ Range based on column 2 and 3 of Table 4 , and on return to medical specialization.

the possibly greater consumption elements in college education. Another intriguing implication is that the apparent, but not clearly documented, stability over time in the rates of return to training (both in school and on the job) may conceal a decline in the rate of return to formal education, given that investment in education seems to have grown faster than in on-the-job training, at least at the lower levels.

These conclusions are hazardous. The rates are not adjusted for ability factors. If there is a greater selectivity (based on ability) for admission into college, differences between adjusted rates in the two sectors may disappear, or reverse.
But this is not at all obvious. More detailed data and intensive research are needed.

III. ON-THE-JOB TRAINING AS A FACTOR IN INCOME AND EMPLOYMENT BEHAVIOR

In the first section of this paper, the economic theory of investment in people was used to bring the very elusive process of on-the-job training under the measuring rod of money. In this section the theory will be used to produce additional measurements and to explain, in part, certain well-known but not wellunderstood patterns of income and employment in population subgroups. The empirical analyses sketched below are no more than preliminary, but perhaps they are sufficiently indicative.

A calculation of (marginal) on-the-job training costs per capita for female college graduates in 1949 provided two estimates: (a) $\$ 830,(b) \$ 2,160$. The comparable figure for males was $\$ 15,700$ (Table 1, col. [2]). The calculation is the same as the one underlying Table 1 . It is based on a comparison of net earnings of college and high-school graduates, given in Table A9. Estimate $(a)$ is based on earnings data adjusted for (multiplied by) labor-force rates of women in the various age groups (Table A9, cols. [3] and [4]); estimate (b) is based on the unadjusted earnings (Table A9, cols. [1] and [2]). The adjustment for participation rates assumes that the return on investment in training of women (at college and on the job) is obtainable only in the labor market. If it is believed that this investment in training results also in the same amount of productivity increase in the "home industry," earnings should not be adjusted by labor-force rates. This certainly cannot be assumed of investments on the job, but may be true of schooling. The estimate $(b)$ based 
on unadjusted earnings is, of course, larger. Both assumptions are extreme, and, in principle, provide limits for a correct estimate. ${ }^{40}$

While formal education costs are not much smaller for females than for males, investments in on-the-job training are very small, about one-tenth (taking a middle figure between the two estimates) of the amounts invested by males. The figures may not be highly reliable, but their smallness is quite reasonable, in the light of investment theory: the average female expects to spend less than half her working life in the labor force. In particular, she has a high probability of dropping out of the work force for prolonged periods of child-rearing soon after, and possibly during, the training period. It is clear that returns on prolonged onthe-job training would be small. Hence pecuniary incentives to invest in on-thejob training leading to higher levels of skill are weak. And even when a girl plans on a career, that is, expects to be permanently attached to the labor force, the opportunity for investing in on-thejob training is likely to be limited. So long as there are some elements of specificity in any training programs or promotional schemes of the firm, the employer will prefer men to women trainees, even if the latter profess occupational ambitions. This also implies that to the extent that women do obtain specific training they bear a larger fraction of the total costs of such training than men and, therefore, that the difference between on-the-job training costs (including those borne by employees) for women and those for men is even larger than is suggested by our estimate.

40 Empirical evidence on labor-force behavior of married women is more consistent with the first than with the second assumption (see my "Labor Force Participation of Married Women," in Aspects of Labor Economics, op. cit.).
Some direct evidence on scant female participation in on-the-job training is provided in a recent international survey. ${ }^{41}$ In all countries surveyed, apprenticeships are shorter for women than for men. They are half the length of male apprenticeships in the United States in bookbinding and in the garment industry, where women concentrate. In other industries, numbers of women apprentices are negligible, perhaps because of physical requirements but not because of any legal obstacles. It is interesting to find that, in contrast to other countries, applications for apprenticeships by women were quite numerous in the early postwar years in Germany and Austria. By 1949 in these countries, the number of skilled women in trades previously considered male was quite pronounced and increasing. Because of the warcaused imbalance in the sex ratio in the young age groups, unfavorable marriage prospects of young females clearly increased worker and employer expectations of their more permanent attachment to the labor force. Larger investment in on-the-job training became economical to both parties. Aside from patriotism, such motivations may play a role in the increased labor-force rates and job-training of women during wars in all countries. And the willingness of employers to train women as well as men is enhanced by governmental subsidies of the training function.

Returning to our estimates: the small amounts of investment in on-the-job training by females were derived from female age-income profiles. This procedure is, of course, equivalent to a hypothesis which emphasizes the lack of on-the-job training as the factor responsible for both the observed flatness of fe-

41 "The Apprenticeships of Women and Girls," International Labor Review, October, 1955. 
males' age-income profiles and the small differential between observed incomes of women of different levels of formal education.

A recent detailed study of income differentials between males and females shows that wage rates approach equality when the detailed job specification is identical for both sexes. ${ }^{42}$ The rougher the occupational classification, the bigger the wage differentials at the higher skill levels. Lack of on-the-job training fits these phenomena quite well. cation of women is more strongly focused on the "consumption" sphere, and returns are in larger part non-pecuniary than for males. Hence the apparently smaller money rate of return.

In Table 6 a 1949 comparison of training costs of Negro and white males indicates much smaller investments in on-the-job training by Negroes, though the investments are not negligible. The investment in on-the-job training is also smaller in relation to investment in formal schooling, suggesting a lesser access

TABLE 6

Costs Per Non-white Male of School and ON-The-Joe

Training, 1949

(In $\$$ Thousands)

\begin{tabular}{|c|c|c|c|c|c|c|}
\hline \multirow{2}{*}{ Educatonal LeVEL } & \multicolumn{2}{|c|}{$\begin{array}{c}\text { Marginal } \\
\text { Costs }\end{array}$} & \multicolumn{2}{|c|}{ Total Costs } & \multicolumn{2}{|c|}{$\begin{array}{l}\text { Total Costs } \\
\text { OF All United } \\
\text { States Males }\end{array}$} \\
\hline & School & $\begin{array}{l}\text { On the } \\
\text { Job }\end{array}$ & School & $\begin{array}{l}\text { On the } \\
\text { Job }\end{array}$ & School & $\begin{array}{l}\text { On the } \\
\text { Job }\end{array}$ \\
\hline College & 8.05 & 3.98 & 13.20 & 7.87 & 15.9 & 24.3 \\
\hline High school. & 3.92 & 0.46 & 5.15 & 3.89 & 5.7 & 8.6 \\
\hline Elementary school. & 1.23 & 3.43 & 1.23 & 3.43 & 1.6 & 3.9 \\
\hline
\end{tabular}

Source: Table A10 and Table 1.

These same phenomena, however, are possibly attributable to differential market discrimination against women appearing at the more skilled job levels and increasing with levels of skill. The calculation based on Table A5 indeed revealed a somewhat lower rate (about two percentage points) of return on total training of women than of men. The lower rate may reflect discrimination. Another explanation which is consistent with the investment hypothesis ${ }^{43}$ is that, in view of the expected smaller rate of participation in the labor market, edu-

${ }^{42}$ H. Sanborn, "Male-Female Income Differentials" (unpublished doctoral dissertation, University of Chicago, 1959). to on-the-job training than to formal education. Again, fragmentary direct evidence abounds on the small proportions of Negroes in apprenticeships and other training programs.

Conversely, the smaller amounts of on-the-job training received by Negroes than by whites is an interpretation of income differentials: the relative flatness of their age-income profiles and the smaller differentials in earnings by edu-

${ }^{43}$ Yet another explanation, suggested by Becker ("Underinvestment in College Education?" op. cit.) is that the personal money returns shown above understate the money returns which actually accrue to women as family members. According to this argument family income differentials are the relevant measures. 
cation (even when the latter are standardized in terms of cost). The lesser onthe-job training relative to school training of Negroes is an element in their occupational distribution. It creates an even lower skill concentration in the occupational distribution than would be predicted by the educational distribution. As in the sex comparison this results in a statistical finding that the ratio of non-white to white incomes declines with increasing level of formal education. ${ }^{44}$

It has long been observed that at lower levels of skill and education workers are affected by a stronger incidence of unemployment than those at higher occupational and educational levels. The reasons for this phenomenon have never been clarified.

In his analysis of investment in people, Becker points out that, for a given demand situation, turnover and unemployment rates are likely to be milder under conditions of specific on-the-job training than elsewhere. Specific training is defined as an investment which increases the worker's marginal product in the firm in which he is trained more than elsewhere. According to this theory marginal products of specifically trained workers exceed their wages, but the latter are higher than in alternative employments. ${ }^{45}$ Hence employers have more incentive to retain such workers, and these have more incentive to remain with the firm. The differential behavior is implicit both for cross-sectional observations and for cyclical changes. In a recent study, a similar hypothesis was elaborated and put to an empirical test by Walter Oi. ${ }^{46}$

${ }^{44}$ See M. Zeman, "A Quantitative Analysis of White-Non-white Income Differentials in the United States" (unpublished doctoral dissertation, University of Chicago, 1955).

${ }^{45}$ Becker, "Investment in People," op. cit.
Oi related the severity of cyclical changes (1929-33) in employment to levels of wages in a particular industry and found an inverse correlation between the two. He also correlated average wages by industry with turnover rates for a number of industries at a given time. Here again the (partial) correlation was negative. Oi interprets his results as favorable evidence for the investment hypothesis, on the assumption that wage levels (by occupation and industry) are a proxy for amounts of specific training.

This is a bold assumption. Even if cross-sectional wage differentials (by occupation and industry) represented returns to training only, these conceptually reflect returns to two forms of training: school training which is "general," and on-the-job training which may be "general" or "specific." It is not easy to see why the total return should be particularly strongly correlated with what is probably the smallest component: that part of on-the-job training which is specific. Oi did not attempt to segregate the explanatory factors into "general" and "specific" components of training because his data did not permit standardizations by education or by age. Without such standardizations the results are ambiguous. The wage rate reflects schooling as well as on-the-job training: a higher rate will prevail with very little on-thejob training but sufficiently more school training. This might obscure the relation which is tested. Conversely, the lack of control for age makes for a spurious correlation between the wage rate and turnover. Larger proportions of younger people in an industry, or occupation, mean both more turnover and lower wages.

In an attempt to get a stronger test of

46 "Labor as a Quasi-fixed Factor of Production" (unpublished doctoral dissertation, University of Chicago, 1961). 
the investment hypothesis and more insight into factors affecting turnover and unemployment, I ran a multiple regression relating a hybrid unemployment and turnover variable to average full-time incomes in 1949 of males in eighty-seven detailed occupations, standardizing by educational level, age, and industrial distribution. The dependent variable $(y)$ is the proportion of wage and salary workers who worked fifty to fifty-two weeks in 1949. This variable reflects both differential turnover and unemployment incidence among the groups, so it is well suited for the purpose. ${ }^{47}$ The independent variables are full-time mean incomes in the occupations $\left(X_{1}\right)$, median years of schooling $\left(X_{2}\right)$, proportion of workers less than twenty-five years old $\left(X_{3}\right)$, and $(X)_{4}$ proportion of workers employed in durable-goods manufacturing and in construction.

The rationale for the choice of independent variables is as follows: according to the investment hypothesis, the turnover plus unemployment variable $Y$ is a positive function of specific training costs, part of which are borne by workers, part by firms. Unfortunately, there are no data or readily available proxies for specific costs. I shall assume that such costs are positively related to the total of on-the-job training. This is a much weaker assumption than that of a positive correlation of specific training costs with wage rates.

Consider now the average wage $X_{1}$ in an occupation. This wage will tend to be higher, the higher is the average education $X_{2}$ and the greater the amount of

${ }^{47}$ The variable is also affected by seasonality. The obvious cases where seasonality is strong had fewer than 50 per cent of workers employed yearround. To avoid arbitrariness, all occupations (more than twenty) with $y<50$ per cent were excluded from the analysis. on-the-job training in the occupation. For given values of $X_{2}$, larger $X_{1}$ will therefore tend to reflect more on-the-job training. Thus the sign of the partial regression coefficient of $X_{1}$ is expected to be positive. Conversely, for given occupational wage levels $X_{1}$, the higher the schooling $X_{2}$, the less on-the-job training in the occupation. Unless formal schooling itself has an effect on turnover and unemployment, the sign at $X_{2}$ should be negative. The two additional variables used in the regression, age, $X_{3}$ and industrial composition, $X_{4}$, standardize for factors other than training. Among persons less than twenty-five years of age there is more job and labor-force mobility than among older people, even when the other variables are held constant. $X_{4}$ crudely standardizes for effects of short-run demand fluctuations by industry.

Using these variables, the following regression was obtained (all variables are measured as deviations from their means; standard errors of regression coefficients are in parentheses):

$$
\begin{array}{r}
y=2.08 X_{1}+1.86 X_{2}-2.29 X_{3}-.74 X_{4} \\
(1.04) \quad(.46) \quad(.68) \quad(.21) \\
R^{2}=.65
\end{array}
$$

All variables are statistically significant. All signs, except that for $X_{2}$, conform to expectations. In particular, the positive effect of $X_{1}$ is consistent with the investment hypothesis.

Even if formal education per se had no effect on employment stability, the effects of on-the-job training (reflected in the coefficient at $X_{1}$ ) would explain the previously described systematic patterns of unemployment rates of workers classified by educational levels. As we have seen in Table 1, more on-the-job 
training is received by workers at higher educational levels.

However, in terms of the investment hypothesis, which emphasizes specific training in this context, the positive sign at $X_{2}$ is puzzling. Could it possibly reverse if the analysis were expanded to include such variables as urbanization, unionization, race, marital status? Such an expansion, if feasible, would be desirable. I experimented with inclusion of two easily accessible variables: $X_{5}$, percentage of males older than fifty-five, and $X_{6}$, percentage of non-whites in an occupation. Neither was statistically significant. Their inclusion did not increase the correlation coefficient, nor did it affect the coefficient of $X_{2}$. The inclusion of the racial variable $X_{6}$, however, lowered the coefficient of $X_{1}$ and weakened its reliability.

Is stability of employment affected by training, regardless of whether it is general or specific, acquired at school or on the job? One could argue, to be monistic, that educational levels are more strongly correlated with specific training than is on-the-job training. For example, the employer may be using information on educational attainment as an index of capability or suitability for selection to specific on-the-job training. If so, the coefficient of education (at $X_{2}$ ) "catches" more of the effects of specific training than does the coefficient at $X_{1}$. However, there may be good reasons for the behavior of $X_{2}$ other than the investment hypothesis, and it remains an open question for some significant exploration of unemployment phenomena.

Another way of discerning the effects of on-the-job training on employment stability is to compare population groups with the same amount of formal education but differing in on-the-job training. Comparisons by race and sex should serve the purpose. As we have seen (in this section and Table 1) the amounts invested in on-the-job training differ substantially among the groups compared within the same educational levels. It also appears that differences in amounts of on-the-job training increase with increasing educational level in both race and sex comparisons. If on-the-job training were a major factor in explaining differentials in employment stability, the investment hypothesis would predict higher unemployment rates for Negroes than for whites at each educational level and an increasing differential in rates the higher the educational level. A similar prediction would apply to the femalemale comparison.

Data shown in Table 7 are differences between unemployment rates of Negro and white males classified by age and education in 1950. Negro unemployment rates are higher in almost all classifications; the difference is negligible at the lowest educational levels and, generally, increases with education. The differentials remain positive, but decrease at the highest educational level. Similar patterns have been observed by Harry Gilman for an occupational breakdown of the Negro and white male labor force, both for cross-sectional differences and cyclical changes. ${ }^{48}$ In the occupational breakdown, the differentials increase with skill level in the "blue-collar" groups; differentials remain positive but the increase is halted in the "white-collar" groups. Additional factors, such as differential industrial attachments of "bluecollar" and "white-collar" groups are likely to be responsible for some of the deviations from the theoretical predictions. A multivariate analysis is clearly

48 "Discrimination and the White-Non-white Unemployment Differentials" (doctoral dissertation, University of Chicago). 
desirable. But, by and large, even the gross comparisons suggest that the investment hypothesis is relevant in explaining differences in unemployment incidence of Negro and white labor. ${ }^{49}$

Comparison of unemployment rates of males and females, classified by education, show only small, apparently ran-

${ }^{49}$ The turnover regression analysis described before is also suggestive: once the levels of education and of on-the-job training were taken into account, the racial factor did not seem to have any discernible effects on turnover plus unemployment. dom, differences (Table 8). The levels are similar and decline with increasing education in both groups. Does this mean that formal education affects unemployment rates and on-the-job training does not? This would be, prima facie, inconsistent with the other findings. A multivariate analysis is needed in which the net effect of the training factor could be isolated, in order to resolve this puzzle..$^{50}$

50 The prevalence of women in cyclically insensitive jobs (clerical, government, teaching, and nursing) is an obviously plausible explanation.

TABLE 7

Negro-White Unemployment Differentials,* By Age and Education, United States Males, Civilian Labor Force, 1950

\begin{tabular}{|c|c|c|c|c|c|c|}
\hline \multirow{2}{*}{$\begin{array}{l}\text { YeARS OF } \\
\text { SCHOOLING }\end{array}$} & \multicolumn{5}{|c|}{ AGE } & \multirow{2}{*}{ Total } \\
\hline & $25-29$ & $30-34$ & $35-44$ & $45-54$ & $55-64$ & \\
\hline $\begin{array}{c}0 \ldots \ldots \ldots \\
1-4 \ldots \ldots \\
5-7 \ldots \ldots \\
8 \ldots \ldots \\
9-11 \ldots \ldots \\
12 \ldots \ldots \\
13-15 \ldots \ldots \\
16 \text { or more. }\end{array}$ & $\begin{array}{r}0.9 \\
0.0 \\
.6 \\
4.4 \\
5.8 \\
5.6 \\
4.8 \\
0.0\end{array}$ & $\begin{array}{l}.8 \\
.2 \\
1.4 \\
3.1 \\
3.5 \\
4.7 \\
4.9 \\
3.0\end{array}$ & $\begin{array}{r}-1.1 \\
.3 \\
1.5 \\
3.3 \\
4.4 \\
4.0 \\
4.0 \\
.9\end{array}$ & $\begin{array}{r}.3 \\
.3 \\
1.3 \\
2.3 \\
3.3 \\
2.8 \\
.4 \\
.8\end{array}$ & $\begin{array}{l}.6 \\
.6 \\
1.3 \\
2.8 \\
2.5 \\
3.9 \\
3.8 \\
1.7\end{array}$ & $\begin{array}{r}-\quad .2 \\
.3 \\
1.8 \\
3.5 \\
4.7 \\
4.4 \\
3.8 \\
1.2\end{array}$ \\
\hline
\end{tabular}

* Negro minus white unemployment rate.

Source: U.S. Census of Population, 1950, Special Reports: Education, Table 9.

TABLE 8

Male-Female Unemployment Differentials, ${ }^{*}$ By Age and Education, CIVILIAN LABOR FORCE, 1950

\begin{tabular}{|c|c|c|c|c|c|}
\hline \multirow{2}{*}{$\begin{array}{l}\text { YeARS OF } \\
\text { SchoOLING }\end{array}$} & \multicolumn{5}{|c|}{ AGE } \\
\hline & $25-29$ & $30-34$ & $35-44$ & $45-54$ & $55-64$ \\
\hline $\begin{array}{r}0 \ldots \ldots \ldots \\
1-4 \ldots \ldots \\
5-7 \ldots \ldots \\
8 \ldots \ldots \\
9-11 \ldots \ldots \\
12 \ldots \ldots \\
13-15 \ldots \ldots \\
16 \text { or more. }\end{array}$ & $\begin{array}{r}2.6 \\
2.5 \\
.5 \\
.3 \\
.8 \\
-.1 \\
-.6 \\
-.8\end{array}$ & $\begin{array}{r}-1.4 \\
2.2 \\
1.2 \\
1.0 \\
.7 \\
.7 \\
.2 \\
.7\end{array}$ & $\begin{array}{r}.3 \\
1.4 \\
.3 \\
.3 \\
.5 \\
.1 \\
.1 \\
.1\end{array}$ & $\begin{array}{r}-.4 \\
.4 \\
.1 \\
-.1 \\
.2 \\
-.3 \\
-.4 \\
-.2\end{array}$ & $\begin{array}{l}-1.5 \\
-1.4 \\
-\quad .4 \\
-.5 \\
-.3 \\
-.6 \\
-.6\end{array}$ \\
\hline
\end{tabular}

* Female minus male unemployment rate.

Source: U.S. Census of Population, 1950, Special Reports, Education, Table 9. 
SUMMARY

The empirical exploration described in this paper was designed to achieve several purposes: (1) to estimate the amount of resources invested in on-thejob training as distinguished from investments in the formal educational system, (2) to estimate rates of return on such investments, (3) to investigate the relevance of these investments to certain well-known but not well-understood patterns of income and employment behavior of population groups.

Since the research was exploratory rather than intensive, the conclusions reached are very tentative. Briefly stated: (1) Investment in on-the-job training is a very large component of total investment in education in the United States economy. Measured in terms of costs, it is as important as formal education for the male labor force and amounts to more than a half of total (male and female) expenditures on school education. Aggregate and per capita investments in on-the-job training have been increasing since 1939, though at a slower rate than investments in formal education. It seems, however, that on-the-job training has grown at a much faster rate at higher skill levels than at lower ones.

(2) The rate of return on selected in- vestments in on-the-job training, such as apprenticeships and medical specialization, was not different from the rate of return on total costs of college education, both unadjusted for ability factors. However, the private return, that is, the return on private costs seems to be higher in formal education than in on-the-job training. These findings raise questions about possible downward biases in the calculated rates of return to education.

(3) The last section of the paper is a preliminary analysis of differential income and employment patterns of population groups, classified by education, occupation, sex, and race. The analyses are incomplete, but they suggest that new empirical knowledge about forms and amounts of investments in people can lead to a significant increase in our understanding of such major areas of economic behavior as income distribution, unemployment incidence, and labor mobility.

Empirical ventures into unexplored territory are hazardous. The margins of error are difficult to assess, and they are likely to be large. At least the findings should provoke further research. The need for more, better, and different data is evident. I hope that some guides for future research do emerge from this preliminary work. 


\section{APPENDIX}

TABLE A1

Net Average Wage and Salary Incomes, ${ }^{*}$ by Years of Schooling and Age, White Urban Males, United States, 1939

(In Dollars)

\begin{tabular}{|c|c|c|c|c|}
\hline \multirow{2}{*}{ AgE } & \multicolumn{4}{|c|}{ Years of Schooling } \\
\hline & 16 or More & 12 & $7-8$ & $1-4$ \\
\hline $\begin{array}{l}\text { Less than } 14 \dagger \ldots \\
14-15+\ldots \ldots \\
16-17 \pm \ldots \\
18-19+\ldots \\
20-21+\ldots \\
22-24 \ldots \\
25-29 \ldots \\
30-34 \ldots \\
35-44 \ldots \\
45-54 \ldots \ldots \\
55-64 \ldots \ldots\end{array}$ & $\begin{array}{l}-850 \\
-115 \\
-103 \\
-452 \\
-400 \\
1,028 \\
1,661 \\
2,395 \\
3,147 \\
3,483 \\
3,147\end{array}$ & $\begin{array}{r}-850 \\
-115 \\
-103 \\
481 \\
755 \\
947 \\
1,244 \\
1,606 \\
2,073 \\
2,286 \\
2,105\end{array}$ & $\begin{array}{r}-850 \\
281 \\
352 \\
443 \\
579 \\
750 \\
959 \\
1,179 \\
1,434 \\
1,570 \\
1,439\end{array}$ & $\begin{array}{r}-340 \\
258 \\
315 \\
373 \\
431 \\
503 \\
648 \\
802 \\
916 \\
1,018 \\
950\end{array}$ \\
\hline
\end{tabular}

* All income data are before tax.

$\dagger$ This now shows total rather than annual costs of elementary school per student.

$\ddagger$ Gross earnings of high-school and of college students were assumed to be one quarter of earnings of elementary-school graduates and of high-school graduates, respectively.

Source: Wage and Salary Incomes: Unpublished National Bureau of Economic Research mate rials of G. S. Becker, based on 1940 Population Census. Direct costs per student were derived from Tables 3, 5, and 6 in T. W. Schultz "Capital Formation by Education,"Journal of Political Economy, December, 1960, and from Biennial Survey of Education in the United States, 1939-40.

TABLE A2

Net Average Incomes, ${ }^{*}$ by Years of Schooling and Age, United States Males, 1949

(In Dollars)

\begin{tabular}{|c|c|c|c|c|}
\hline \multirow{2}{*}{ AGE } & \multicolumn{4}{|c|}{ Years of Schooling } \\
\hline & $16+$ & 12 & 8 & $1-3$ \\
\hline $\begin{array}{l}\text { Less than } 14 \dagger \\
14-17 \pm \ldots \ldots \\
18-19 \pm \ldots \\
20-21 \ddagger \ldots \\
22-24 \ldots \\
25-29 \ldots \\
30-34 \ldots \\
35-44 \ldots \\
45-54 \ldots \\
55-64 \ldots \ldots\end{array}$ & $\begin{array}{r}-1,576 \\
-205 \\
-910 \\
-753 \\
2,284 \\
3,441 \\
4,846 \\
7,085 \\
8,116 \\
7,65.5\end{array}$ & $\begin{array}{r}-1,576 \\
-205 \\
1,071 \\
1,745 \\
2,356 \\
2,975 \\
3,576 \\
4,055 \\
4,689 \\
4,548\end{array}$ & $\begin{array}{r}-1,576 \\
676 \\
1,079 \\
1,523 \\
1,929 \\
2,341 \\
2,680 \\
3,029 \\
3,247 \\
3,010\end{array}$ & $\begin{array}{r}-394 \\
670 \\
720 \\
952 \\
1,192 \\
1,474 \\
1,667 \\
1,814 \\
1,990 \\
1,892\end{array}$ \\
\hline
\end{tabular}

* See n. ${ }^{*}$ in Table A1. Here income includes property income.

† See $\mathrm{n}$. $\dagger$ in Table A1.

† See $\mathbf{n} . \ddagger$ in Table A1.

Source: Income data derived from 1950 Census of Fopulation, Ser. P-E, No. 5B, Education, Tables 12 and 13 (also H. P. Miller, "Income in Relation to Education," American Economic Review, December, 1960, Table 1. Direct costs per student derived from T. W. Schultz, op. cit., and Biennial Survey of Education, 1948-50. 
TABLE A3

Net Average Incomes, ${ }^{*}$ By Years of Schooling and Age, United States Males, 1958

(In Dollars)

\begin{tabular}{|c|c|c|c|c|}
\hline \multirow{2}{*}{ AGE } & \multicolumn{4}{|c|}{ Years of Schooling } \\
\hline & $16+$ & 12 & 8 & $0-4$ \\
\hline $\begin{array}{l}\text { Less than } 14 \uparrow \ldots \\
14-17 \ddagger \ldots \ldots \\
18-21 \ddagger \ldots \\
22-24 \ldots \ldots \\
25-29 \ldots \ldots \\
30-34 \ldots \ldots \\
35-44 \ldots \ldots \\
45-54 \ldots \ldots \\
55-64 \ldots \ldots\end{array}$ & $\begin{array}{r}-2,400 \\
-224 \\
-682 \\
3,663 \\
5,723 \\
7,889 \\
10,106 \\
11,214 \\
10,966\end{array}$ & $\begin{array}{r}-2,400 \\
-224 \\
2,800 \\
3,537 \\
4,381 \\
5,182 \\
6,007 \\
6,295 \\
6,110\end{array}$ & $\begin{array}{r}-2,400 \\
1,208 \\
1,910 \\
2,520 \\
3,223 \\
3,848 \\
4,403 \\
4,337 \\
3,960\end{array}$ & $\begin{array}{l}-600 \\
1,080 \\
1,532 \\
1,931 \\
2,387 \\
2,757 \\
3,023 \\
3,008 \\
2,956\end{array}$ \\
\hline
\end{tabular}

Source: Income data derived from the March, 1959, Current Population Survey, and Miller, op cit. Direct costs per student derived from Statistical Abstract of the United States, 1960.

* See $\mathrm{n} . *$ in Table A2.

$\dagger$ See $n . \dagger$ in Table A1.

$\ddagger$ See $\mathrm{n} . \ddagger$ in Table A1.

TABLE A4

ILLUSTRATIVE CALCULATION OF ANNUAL INCREMENTAL COSTS OF INVESTMENT IN SCHOOLING AND IN ON-THE-JOB TRAINING Male College Graduates, 1939 $(r=11.0 \text { Per Cent })^{*}$

\begin{tabular}{|c|c|c|c|c|c|c|}
\hline Age & $\begin{array}{c}\text { Net Earnings } \\
\text { of High } \\
\text { School } \\
\text { Graduates } \dagger \\
\text { (1) }\end{array}$ & $\begin{array}{c}\text { Net Earnings } \\
\text { of College } \\
\text { Graduates } \dagger \\
\text { (2) }\end{array}$ & $\begin{array}{c}\text { Differentials } \\
\text { in Earnings } \\
([1]-[2]) \\
\text { (3) }\end{array}$ & $\begin{array}{c}\text { Returns on } \\
\text { Last Year's } \\
\text { Cost } \\
\left(r \cdot C_{j-i}\right) \\
\text { (4) }\end{array}$ & $\begin{array}{c}\text { Return on All } \\
\text { Previous Costs } \\
(j-1 \\
r \cdot \Sigma C_{k} \\
k=18) \\
(5)\end{array}$ & $\begin{array}{c}\text { Cost } \ddagger \text { at } \\
\text { Age } j \\
([3]+[5]) \\
\text { (6) }\end{array}$ \\
\hline $\begin{array}{l}18 \ldots \\
19 \ldots \\
20 \ldots \\
21 \ldots \\
22 \ldots \\
23 \ldots \\
24 \ldots \\
25 \ldots \\
26 \ldots \\
27 \ldots \\
28 \ldots \\
29 \ldots \\
30 \ldots \\
31 \ldots \\
32 \ldots \\
33 \ldots \\
34 \ldots \\
35 \ldots \\
36 \ldots \\
37 \ldots \\
38 \ldots \\
39 \ldots\end{array}$ & $\begin{array}{r}409 \\
563 \\
717 \\
793 \\
870 \\
947 \\
1,021 \\
1,095 \\
1,169 \\
1,244 \\
1,316 \\
1,388 \\
1,460 \\
1,533 \\
1,606 \\
1,668 \\
1,730 \\
1,792 \\
1,854 \\
1,916 \\
1,978 \\
2,041\end{array}$ & $\begin{array}{l}-468 \\
-437 \\
-407 \\
-391 \\
870 \\
1,028 \\
1,186 \\
1,344 \\
1,502 \\
1,661 \\
1,807 \\
1,954 \\
2,101 \\
2,245 \\
2,395 \\
2,495 \\
2,595 \\
2,695 \\
2,795 \\
2,895 \\
2,995 \\
3,096\end{array}$ & $\begin{array}{r}877 \\
1,000 \\
1,124 \\
1,184 \\
0 \\
-81 \\
-165 \\
-249 \\
-333 \\
-417 \\
-491 \\
-566 \\
-641 \\
-715 \\
-789 \\
-827 \\
-865 \\
-903 \\
-941 \\
-979 \\
-1,017 \\
-1,055\end{array}$ & $\begin{array}{r}96 \\
121 \\
148 \\
170 \\
59 \\
56 \\
53 \\
50 \\
46 \\
42 \\
39 \\
35 \\
30 \\
25 \\
20 \\
18 \\
16 \\
13 \\
10 \\
7 \\
4\end{array}$ & $\begin{array}{r}96 \\
217 \\
365 \\
535 \\
594 \\
650 \\
703 \\
753 \\
799 \\
841 \\
880 \\
915 \\
945 \\
970 \\
990 \\
1,008 \\
1,024 \\
1,037 \\
1,047 \\
1,054 \\
1,058\end{array}$ & $\begin{array}{r}877 \\
1,096 \\
1,341 \\
1,549 \\
535 \\
513 \\
485 \\
454 \\
420 \\
382 \\
350 \\
314 \\
274 \\
230 \\
181 \\
163 \\
143 \\
121 \\
96 \\
68 \\
37 \\
3\end{array}$ \\
\hline
\end{tabular}

* Obtained by equating to zero the present value of col. (3) (continued to age 65).

$\dagger$ Age-earnings profiles from Table A1, interpolated within age groups.

$\ddagger$ School cost for ages 18-21; on-the-job training cost thereafter. 
TABLE A5*

Estimated Cost of Schooling and of On-The-Job Training, By Age And Level of Education, United States Males, 1939

\begin{tabular}{|c|c|c|c|c|c|c|c|c|c|}
\hline \multirow[b]{2}{*}{$\triangle 1 G E$} & \multicolumn{3}{|c|}{ Marginal Costs (\$) } & \multicolumn{3}{|c|}{ Total Costs $(\$)$} & \multicolumn{3}{|c|}{ “EMployment" (Thousands) } \\
\hline & $\begin{array}{c}\text { Elementary } \\
\text { School } \\
(r=20.9) \\
(1)\end{array}$ & $\begin{array}{c}\text { High } \\
\text { School } \\
(r=12.5) \\
(2)\end{array}$ & $\begin{array}{c}\text { College } \\
(r=11.0) \\
(3)\end{array}$ & $\begin{array}{c}\text { Elementary } \\
\text { School } \\
([4]=[1]) \\
(4)\end{array}$ & $\begin{array}{c}\text { High } \\
\text { School } \\
([1]+[2]) \\
(5)\end{array}$ & $\begin{array}{c}\text { College } \\
([1]+[2]+ \\
[3]) \\
(6)\end{array}$ & $\begin{array}{c}\text { Elemen- } \\
\text { tary } \\
\text { School } \\
(7)\end{array}$ & $\begin{array}{c}\text { High } \\
\text { School } \\
(8)\end{array}$ & $\begin{array}{c}\text { College } \\
(9)\end{array}$ \\
\hline 14. & 510 & 0 & 0 & 510 & 510 & 510 & & & \\
\hline 14. & 85 & 388 & 0 & 85 & 388 & 388 & 105.7 & & 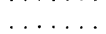 \\
\hline 15. & 98 & 455 & 0 & 98 & 455 & 455 & 105.7 & & \\
\hline 16. & 110 & 545 & 0 & 110 & 545 & 545 & 193.2 & & \\
\hline 17. & 125 & $\underline{64} \underline{3}$ & 0 & 125 & $64 \underline{3}$ & 643 & 193.2 & & \\
\hline 18. & 142 & $25 \overline{4}$ & 877 & 142 & 396 & 877 & 246.1 & 283.1 & \\
\hline 19. & 133 & 200 & 1,096 & 133 & 333 & 1,096 & 246.1 & 283.1 & . \\
\hline 20. & 122 & 139 & 1,341 & 122 & 261 & 1,341 & 288.7 & 349.6 & \\
\hline 21 . & 108 & 148 & $1, \underline{549}$ & 108 & 256 & 1,549 & 288.7 & 349.6 & \\
\hline 22 . & 92 & 158 & $-\frac{1}{535}$ & 92 & 250 & $-\frac{12}{785}$ & 322.8 & 377.9 & 164.3 \\
\hline 23. & 71 & 170 & 513 & 71 & 241 & 754 & 322.8 & 377.9 & 156.7 \\
\hline 24. & 70 & 169 & 485 & 70 & 239 & 724 & 322.8 & 377.9 & 149.9 \\
\hline 25 . & 69 & 168 & 454 & 69 & 237 & 691 & 368.7 & 331.2 & 131.1 \\
\hline 26. & 67 & 167 & 420 & 67 & 234 & 654 & 368.7 & 331.2 & 129.1 \\
\hline 27 . & 65 & 166 & 382 & 65 & 231 & 613 & 368.7 & 331.2 & 127.4 \\
\hline 28. & 65 & 159 & 350 & 65 & 224 & 574 & 368.7 & 331.2 & 127.1 \\
\hline 29. & 66 & 151 & 314 & 66 & 217 & 531 & 368.7 & 331.2 & 128.8 \\
\hline 30 . & 67 & 142 & 274 & 67 & 209 & 483 & 375.7 & 256.4 & 119.7 \\
\hline 31 . & 68 & 131 & 230 & 68 & 199 & 429 & 375.7 & 256.4 & 112.6 \\
\hline 32 . & 69 & 118 & 181 & 69 & 187 & 368 & 375.7 & 256.4 & 108.6 \\
\hline 33. & 64 & 105 & 163 & 64 & 169 & 332 & 375.7 & 256.4 & 104.7 \\
\hline 34. & 58 & 90 & 143 & 58 & 148 & 291 & 375.7 & 256.4 & 101.2 \\
\hline 35. & 51 & 73 & 121 & 51 & 124 & 245 & 360.4 & 167.1 & 90.0 \\
\hline 36. & 42 & 54 & 96 & 42 & 96 & 192 & 360.4 & 167.1 & 67.2 \\
\hline 37. & 31 & 37 & 68 & 31 & 67 & 135 & 360.4 & 167.1 & 67.2 \\
\hline 38. & 18 & 14 & 37 & 18 & 32 & 69 & 360.4 & 167.1 & 67.2 \\
\hline 39. & 4 & & 3 & 4 & 4 & 7 & 360.4 & 167.1 & 67.2 \\
\hline \multicolumn{4}{|c|}{ Total cost of on-the-job training. } & 2,000 & 4,400 & 7,900 & & & \\
\hline
\end{tabular}

* Cols. (1), (2), (3) obtained by the method represented by eq. (1) in the text and illustrated in Table A4. Schooling costs are above the broken lines; on-the-job costs below it. $r$ is the internal rate of return on the marginal costs. Columns terminate at ages when costs become zero. Thereafter they turn negative and positive for several runs; but they are small, and their sum is negligible.

Cols. (4), (5), (6) are horizontally cumulated costs for each year of training, separately for schooling (above the broken line), and for training on the job (below the broken line). Vertical sums (rounded) of training costs in col. (4), (5), (6) are shown in the bottom row. These are entered in col. (5) of text Table 1. Figures in col. (2) of text Table 1 are first differences of figures in col. (5), not vertical sums of col. $(1,2,3)$ in Tables A $5-A 7$.

Col. (7) includes male workers with eight years of education, plus half the workers with less than eight years and half the workers with more than eight and less than twelve years of schooling.

Col. (8) includes workers who have high-school education, plus half of the "some high-school" and of "some college" groups.

Col. (9) includes workers who have college education or more, plus half of the "some college" group

In principle, the employment figures (cols. [7], [8], [9]) are supposed to represent numbers of workers of a given educational category by numbers of years elapsed since completion of schooling, and not by age. Clearly, all college students do not graduate at age twenty-two. Very few graduate at an earlier age, but large proportions do at later ages. The number of college graduates aged twentytwo, therefore, severely underestimates the number of persons who are in their first year after college graduation. The bias in numbers of workers, of course, reverses at later ages. However, since higher costs of on-the-job training decline with age, aggregate costs (Table 2) would be underestimated. This bias is roughly corrected at the college level (col. [9]) by the use of graduation rather than employment data. No such correction was made at the lower levels. Graduation at the lower levels cannot be equated with labor-force participation, and the problem of bias is less acute anyway: age dispersion at graduation and cost figures are much smaller.

Source: Cols. (7), (8), (9) 1940 Census of Population, Education, Tables 75, 76, 1950 Census of Population, G-E, No. 5B, Education. Table 9. Bureau of Labor Statistics, Special Labor Force Reports, No. 1, February, 1960, Table D; United States Department of Health, Education, and Welfare, Earned Degrees Conferred by Higher Educational Institutions, 1948-58; Biennial Survey of Educaiton, before 1948 . 
TABLE A6*

Estimated Costs of Schooling AND of ON-THE-Job TRAINING, BY AGE AND LEVEl of Education, UnIted States MaLes, 1949

\begin{tabular}{|c|c|c|c|c|c|c|c|c|c|}
\hline \multicolumn{4}{|c|}{ Marginat. Costs $(\$)$} & \multicolumn{3}{|c|}{ Total Costs $(\$)$} & \multicolumn{3}{|c|}{ "EMPLOYMENT" (ThOUSANDS) } \\
\hline Age & $\begin{array}{c}\text { Elemen- } \\
\text { tary } \\
\text { School } \\
(r=22.2) \\
(1)\end{array}$ & $\begin{array}{c}\text { High } \\
\text { School } \\
(r=11.8) \\
(2)\end{array}$ & $\begin{array}{c}\text { College } \\
(r=10.6) \\
(3)\end{array}$ & $\begin{array}{c}\text { Elemen- } \\
\text { tary } \\
\text { School } \\
(4)\end{array}$ & $\begin{array}{c}\text { High } \\
\text { School } \\
(5)\end{array}$ & $\begin{array}{c}\text { College } \\
(6)\end{array}$ & $\begin{array}{c}\text { Elemen- } \\
\text { tary } \\
\text { School } \\
(7)\end{array}$ & $\begin{array}{c}\text { High } \\
\text { School } \\
(8)\end{array}$ & $\begin{array}{c}\text { College } \\
\text { (9) }\end{array}$ \\
\hline $\begin{array}{l}14 \ldots \\
14 \ldots \\
15 \ldots \\
16 \ldots \\
17 \ldots \\
18 \ldots \\
19 \ldots \\
20 \ldots \\
21 \ldots \\
22 \ldots \\
23 \ldots \\
24 \ldots \\
25 \ldots \\
26 \ldots \\
27 \ldots \\
28 \ldots \\
29 \ldots \\
30 \ldots \\
31 \ldots \\
32 \ldots \\
33 \ldots \\
34 \ldots \\
35 \ldots \\
36 \ldots \\
37 \ldots \\
38 \ldots \\
39 \ldots \\
40 \ldots \\
41 \ldots \\
42 \ldots \\
43 \ldots \\
\end{array}$ & 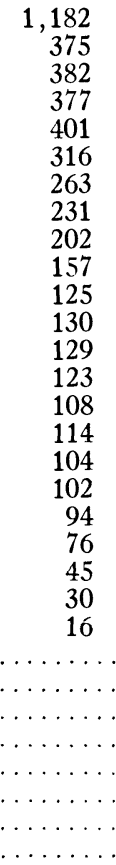 & $\begin{array}{r}0 \\
777 \\
939 \\
1,121 \\
1,309 \\
544 \\
538 \\
441 \\
383 \\
363 \\
329 \\
315 \\
307 \\
293 \\
268 \\
264 \\
255 \\
225 \\
196 \\
148 \\
161 \\
154 \\
167 \\
151 \\
143 \\
149 \\
156 \\
129 \\
89 \\
65 \\
17\end{array}$ & $\begin{array}{r}0 \\
0 \\
0 \\
0 \\
0 \\
1,881 \\
2,268 \\
2,778 \\
3,304 \\
1,143 \\
1,273 \\
1,329 \\
1,335 \\
1,311 \\
1,294 \\
1,267 \\
1,260 \\
1,252 \\
1,218 \\
1,150 \\
1,075 \\
1,008 \\
884 \\
763 \\
599 \\
432 \\
228 \\
47 \\
17\end{array}$ & $\begin{array}{r}1,182 \\
375 \\
382 \\
377 \\
401 \\
316 \\
263 \\
231 \\
202 \\
157 \\
125 \\
130 \\
129 \\
123 \\
108 \\
114 \\
104 \\
102 \\
94 \\
76 \\
45 \\
30 \\
16 \\
\ldots \ldots\end{array}$ & $\begin{array}{r}1,182 \\
777 \\
939 \\
1,121 \\
1,309 \\
860 \\
801 \\
672 \\
585 \\
520 \\
454 \\
445 \\
436 \\
416 \\
376 \\
378 \\
359 \\
327 \\
290 \\
224 \\
206 \\
184 \\
183 \\
151 \\
143 \\
149 \\
156 \\
129 \\
89 \\
65 \\
17\end{array}$ & $\begin{array}{r}1,182 \\
777 \\
939 \\
1,121 \\
1,309 \\
1,881 \\
2,268 \\
2,778 \\
3,304 \\
1,663 \\
1,727 \\
1,774 \\
1,771 \\
1,727 \\
1,670 \\
1,640 \\
1,619 \\
1,579 \\
1,508 \\
1,374 \\
1,281 \\
1,192 \\
1,067 \\
914 \\
742 \\
581 \\
384 \\
176 \\
106 \\
65 \\
17\end{array}$ & $\begin{array}{r}98.3 \\
98.3 \\
184.1 \\
184.1 \\
233.1 \\
233.1 \\
244.7 \\
244.7 \\
285.1 \\
285.1 \\
285.1 \\
303.5 \\
303.5 \\
303.5 \\
303.5 \\
303.5 \\
329.5 \\
329.5 \\
329.5 \\
329.5 \\
329.5 \\
379.3 \\
\ldots \ldots . .\end{array}$ & $\begin{array}{r}425.5 \\
425.5 \\
415.7 \\
415.7 \\
443.7 \\
443.7 \\
443.7 \\
476.8 \\
476.8 \\
476.8 \\
476.8 \\
476.8 \\
442.1 \\
442.1 \\
442.1 \\
442.1 \\
442.1 \\
387.5 \\
387.5 \\
387.5 \\
387.5 \\
387.5 \\
267.5 \\
267.5 \\
267.5 \\
267.5\end{array}$ & $\begin{array}{l}\ldots \ldots \ldots \\
\ldots \ldots \\
\ldots \ldots \ldots \\
\ldots \ldots \ldots \\
\ldots \ldots \ldots \\
\ldots \ldots \ldots \\
\ldots \ldots \ldots \\
\cdots \ldots \ldots \\
342.0 \\
266.7 \\
204.7 \\
118.3 \\
114.6 \\
112.0 \\
138.6 \\
169.7 \\
169.2 \\
173.1 \\
164.2 \\
157.8 \\
150.1 \\
139.5 \\
125.8 \\
125.8 \\
125.8 \\
125.8 \\
115.8 \\
115.8 \\
115.8 \\
115.8\end{array}$ \\
\hline \multicolumn{4}{|c|}{ Total cost of on-the-job training. } & 3,902 & 8,600 & 24,300 & & & \\
\hline
\end{tabular}

* See notes to Table A5. 
TABLE A7*

Estimated Costs of Schooling and of On-The-Job Training, by Age and LEVEL OF EduCATION, UNited STATES MALES, 1958

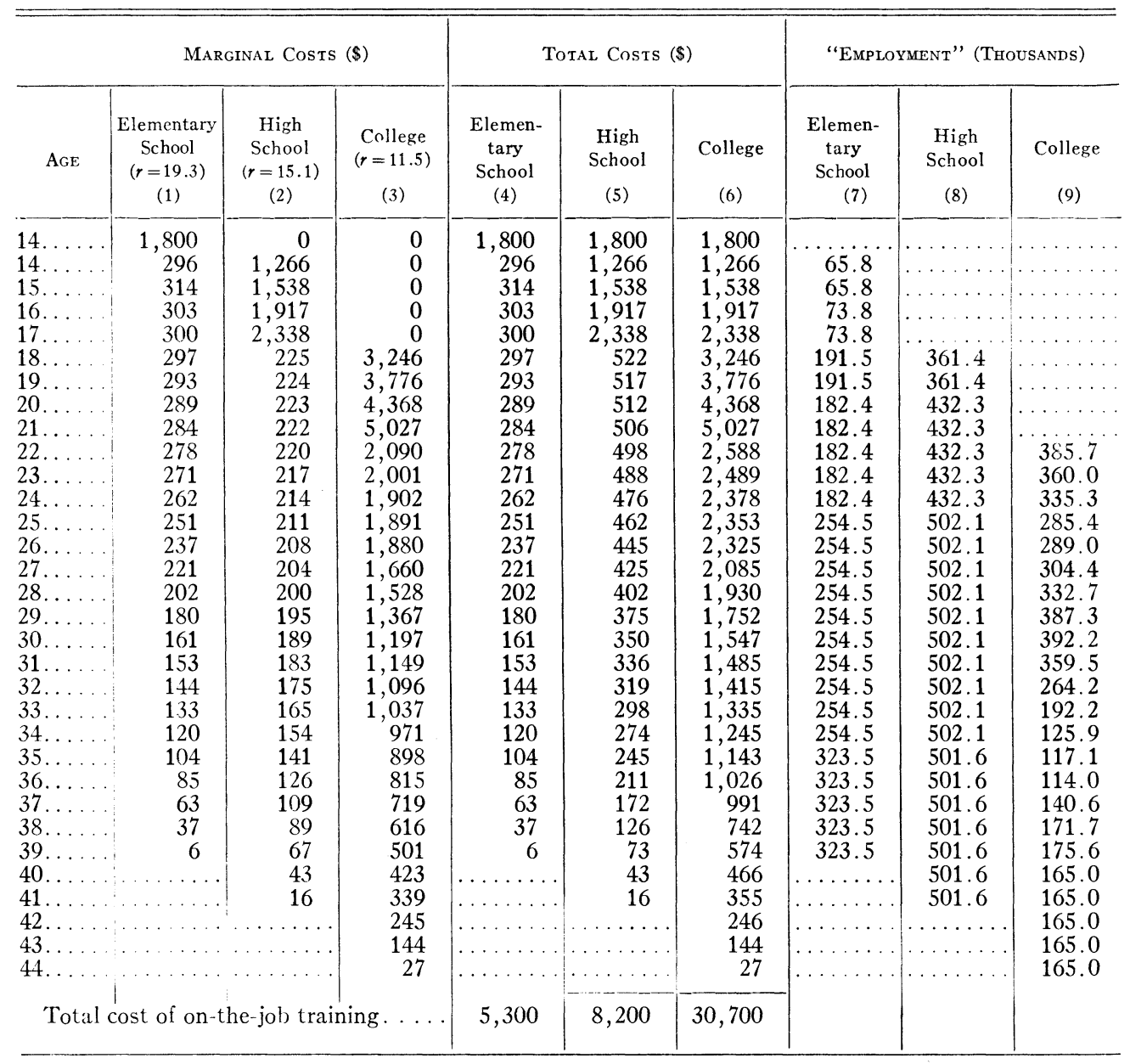

* See notes to Table A5. 
TABLE A8

Average Wage and Salary Income and Median Years of Schooling of Apprentices, OPERATIVES, AND JOURNEYMEN IN THREE INDUSTRY GROUPS, 1949

\begin{tabular}{|c|c|c|c|c|c|c|}
\hline & \multicolumn{2}{|c|}{$\begin{array}{l}\text { Metal Trades } \\
(4 \text { Years })^{*}\end{array}$} & \multicolumn{2}{|c|}{$\begin{array}{c}\text { Printing and Publishing } \\
(5.5 \text { YeARS }) *\end{array}$} & \multicolumn{2}{|c|}{$\begin{array}{l}\text { CONSTRUCTION } \\
(3.8 \text { YeARS })^{*}\end{array}$} \\
\hline & Schooling & Wage & Schooling & Wage & Schooling & Wage \\
\hline $\begin{array}{l}\text { Apprentices } \ldots \ldots \ldots \\
\text { Operatives (in same industry) } \ldots \ldots \\
\text { With more schooling } \dagger \ldots \ldots \ldots \ldots \\
\text { Assuming a } 10 \text { per cent return on } \\
\quad \text { schooling } \ddagger \ldots \ldots \ldots \ldots \ldots \ldots \ldots \ldots \\
\text { Journeymen } \ldots \ldots \ldots \ldots \ldots \ldots \ldots\end{array}$ & $\begin{array}{r}12.2 \\
9.0 \\
11.3\end{array}$ & $\begin{array}{r}\$ 2,480 \\
3,015 \\
3,286 \\
\\
3,415 \\
3,534\end{array}$ & $\begin{array}{l}12.2 \\
10.4 \\
11.3\end{array}$ & $\begin{array}{r}\$ 2,525 \\
3,239 \\
3,500 \\
\\
3,540 \\
4,138\end{array}$ & $\begin{array}{r}11.8 \\
8.8 \\
11.3\end{array}$ & $\begin{array}{r}\$ 2,576 \\
2,937 \\
3,208 \\
\\
3,340 \\
3,216\end{array}$ \\
\hline
\end{tabular}

* Average length of apprenticeship.

$\dagger$ In industries where they are found.

$\ddagger$ This return is added to the wage figure in second row. $k=$ row 5 minus row $2 ; d_{1}=$ row 2 minus row 1 ; $d_{2}=$ row 3 minu row $1 ; d_{3}=$ row 4 minus row 1 .

Source: U.S. Census of Population, 1950: Special Reports, Occupational Characteristics, Tables 10 and 23.

TABLE A9

NET AVERAGE INCOMES OF FEMALES WITH AND WITHOUT ADJUSTMENT FOR LABOR-FORCE PARTiCIPATION RATES, BY LEVEL OF EDUCATION AND AGE, 1949

(In Dollars)

\begin{tabular}{|c|c|c|c|c|}
\hline \multirow[b]{2}{*}{ Age } & \multicolumn{2}{|c|}{ UNADJUSTED } & \multicolumn{2}{|c|}{ ADJUSTED* } \\
\hline & $\begin{array}{c}\text { High } \\
\text { School } \\
\text { (1) }\end{array}$ & $\begin{array}{c}\text { College } \\
\text { (2) }\end{array}$ & $\begin{array}{c}\text { High } \\
\text { School } \\
\text { (3) }\end{array}$ & $\begin{array}{c}\text { College } \\
(4)\end{array}$ \\
\hline $\begin{array}{l}18-19 \ldots \ldots \\
20-21 \ldots \ldots \\
22-24 \ldots \ldots \\
25-29 \ldots \ldots \\
30-34 \ldots \ldots \\
35-44 \ldots \ldots \\
45-54 \ldots \ldots \\
55-64 \ldots \ldots \ldots\end{array}$ & $\begin{array}{l}970 \\
1,468 \\
1,614 \\
1,635 \\
1,674 \\
1,859 \\
2,062 \\
1,968\end{array}$ & $\begin{array}{l}-786 \\
-706 \\
1,900 \\
2,120 \\
2,293 \\
2,600 \\
2,907 \\
2,974\end{array}$ & $\begin{array}{r}970 \\
1,468 \\
734 \\
520 \\
532 \\
662 \\
767 \\
559\end{array}$ & $\begin{array}{r}-786 \\
-706 \\
1,313 \\
939 \\
1,016 \\
1,277 \\
1,608 \\
1,448\end{array}$ \\
\hline
\end{tabular}

* Observed average incomes multiplied by labor-force rates after age twenty-two. Rates from Gertrude Bancroft, The American Labor Force (New York: John Wiley \& Son, 1958), Table D, p. 62.

Source: U.S. Census of Population, 1950, Special Reports, Education, Tables 10 and 12.
TABLE A10

MEAN INCOMES OF NON-WHITE MALES, BY AgE AND EduCATION LEVEL, UNITED STATES, 1950 (In Dollars)

\begin{tabular}{|c|c|c|c|c|}
\hline \multirow[b]{2}{*}{ AgE } & \multicolumn{4}{|c|}{ EdUCATION } \\
\hline & $\begin{array}{c}\text { No } \\
\text { School- } \\
\text { ing }\end{array}$ & $\begin{array}{c}\text { Elemen } \\
\text { tary } \\
\text { School }\end{array}$ & $\begin{array}{c}\text { High } \\
\text { School }\end{array}$ & $\begin{array}{l}\text { College } \\
\text { or More }\end{array}$ \\
\hline $\begin{array}{l}18-19 \ldots \ldots \\
20-21 \ldots \ldots \\
22-24 \ldots \ldots \\
25-29 \ldots \ldots \\
30-34 \ldots \ldots \\
35-44 \ldots \ldots \\
45-54 \ldots \ldots \\
55-64 \ldots \ldots\end{array}$ & $\begin{array}{r}570 \\
808 \\
997 \\
1,109 \\
1,187 \\
1,300 \\
1,254 \\
1,108\end{array}$ & $\begin{array}{l}809 \\
1,177 \\
1,520 \\
1,747 \\
1,916 \\
2,008 \\
2,068 \\
1,921\end{array}$ & $\begin{array}{l}809 \\
1,349 \\
1,783 \\
2,137 \\
2,374 \\
2,453 \\
2,419 \\
2,238\end{array}$ & $\begin{array}{l}\cdots \cdots \\
1,555 \\
2,121 \\
2,950 \\
3,437 \\
3,639 \\
3,246\end{array}$ \\
\hline
\end{tabular}

Source: Computed from distributions given in U.S. Censu of Population, 1950, Vol. IV, Special Reports, Education, Table 12. 